Saint Louis University School of Law Scholarship Commons

All Faculty Scholarship

2011

\title{
Does It Matter What We Say About Legal Interpretation?
}

Karen Petroski

Saint Louis University School of Law

Follow this and additional works at: https://scholarship.law.slu.edu/faculty

Part of the Legal Education Commons, and the Legal Writing and Research Commons

\section{Recommended Citation}

Petroski, Karen. Does It Matter What We Say About Legal Interpretation? (2011).

This Working Paper is brought to you for free and open access by Scholarship Commons. It has been accepted for inclusion in All Faculty Scholarship by an authorized administrator of Scholarship Commons. For more information, please contact erika.cohn@slu.edu, ingah.daviscrawford@slu.edu. 


\title{
DOES IT MATTER WHAT WE SAY
}

\section{ABOUT LEGAL INTERPRETATION?}

\author{
Karen Petroski
}

Despite a common interest in justifying their scholarly output, legal academics have resisted seeing how their work is molded by the institutional environment in which it is produced, and not just by legal doctrine, ideology, or individual perspectives. This paper presents a case study from this neglected perspective, considering the shape of scholarship on legal interpretation in light of the social conditions of its production. After a brief discussion of the debates over whether scholarship (and which scholarship) matters, the paper explores how such concerns are addressed in various academic accounts of scholars' textual practices. It then offers some initial conclusions from an original study of the 154 most-cited articles on legal interpretation published in American law reviews. Early framings of the subject shaped later work in familiar ways. But the patterns disclosed by the citation relationships among the articles suggest some surprising conclusions. Scholars working in the area seem to understand their contributions in a way that is at odds with the institutional dynamics of their efforts. These patterns further indicate that legal academics' failure to develop a specifically legal scholarly discourse, in some respects a strength of legal scholarship, may carry seldom-noted risks in work on this topic.

\section{CONTENTS}

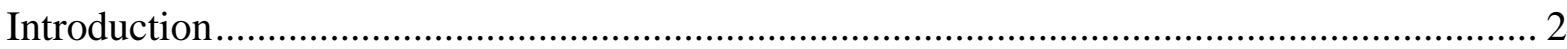

I. The Debate Over the Value of Scholarship ............................................................... 3

A. A Brief Introduction to the Debate Over Legal Scholarship ...................................... 3

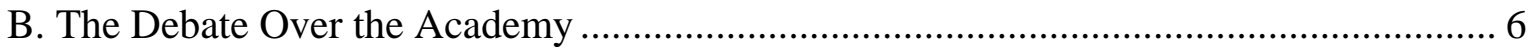

C. Special Features of the Legal Academy ................................................................... 7

II. Academic Inquiry as a Social Phenomenon ................................................................. 10

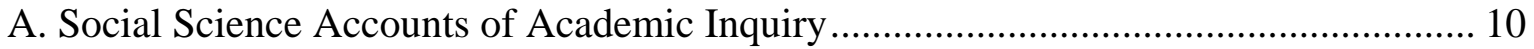

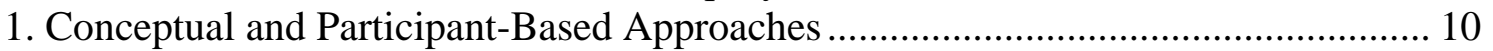

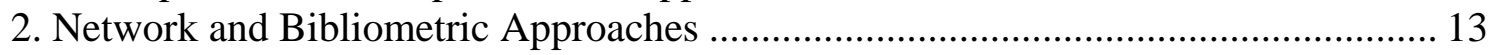

B. The Analysis of Text Networks in Legal Scholarship ........................................... 17

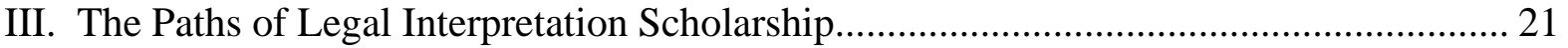

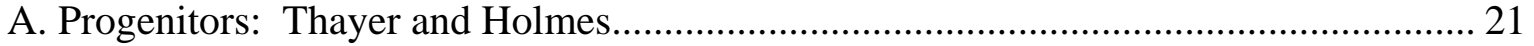

B. The Withering of Interest in Contract Interpretation ............................................... 25

C. The Chevron Phenomenon ............................................................................... 26

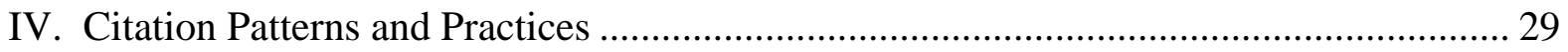

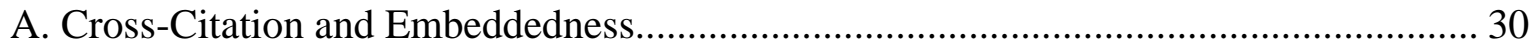

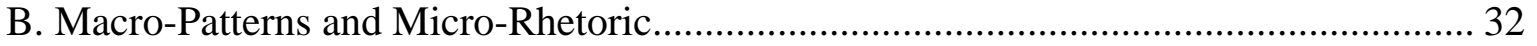

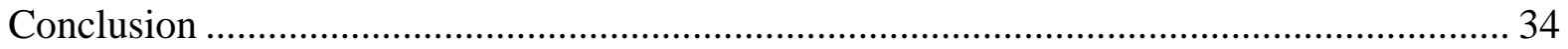

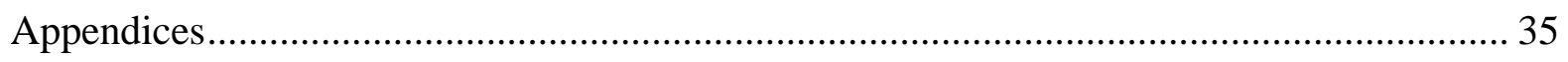

\footnotetext{
* Assistant Professor, Saint Louis University School of Law. Thanks to Richard Delgado and Anders Walker for helpful comments and suggestions.
} 


\section{INTRODUCTION}

Concerns about the value of legal scholarship have been around a long time. In part, such concerns are symptoms of a recurring crisis in Western higher education. In part, however, they are specific to the legal academy, which generates a growing volume of scholarship each year ${ }^{1}$ and occupies a unique position in American higher education, with traditionally close ties to the nonacademic world of legal practice and politics.

Debates about the value of scholarship on the subject of legal interpretation have not always been as contentious; there is some indication that nonacademic legal professionals find such scholarship directly relevant to their work. ${ }^{2}$ But the question is as acute in this subject area as any other. Indeed, some legal scholarship addressing issues of interpretation may be not useless, but positively counterproductive. The specific nature of this risk becomes clearest if we consider not only the effects that legal scholarship has on the nonacademic world-the traditional focus of arguments concerning the value of legal scholarship-but also the conditions of production of that scholarship, especially as those conditions are legible in the material records of scholarly efforts, scholarly publications themselves.

The first half of this paper contextualizes this inquiry. Part I outlines the debate over the value of scholarship, briefly describing its history in the legal context, its analogues in wider debates about the role of the academy, and the institutional peculiarities of the legal academy that complicate the debates in this context. Part II explores approaches to critical analysis of the production of scholarship, especially the patterns exhibited by scholarly textual practices, including citation. The focus is on approaches previously neglected in legal scholars' selfanalysis, especially from the fields of sociology, information science, and communications. Curiously, despite legal academics’ acute self-awareness, sustained desire to legitimate their

\footnotetext{
${ }^{1}$ For example, the Hein Online journal database indexed 33,847 articles in 2008, 12,342 in 1968, 4,629 in 1928, and 1,734 in 1908.

${ }^{2}$ See Deborah J. Merritt \& Melanie Putnam, Judges and Scholars: Do Courts and Scholarly Journals Cite the Same Law Review Articles?, 71 CHI.-KENT L. REV. 872, 882-83 (1996) (finding that scholarship on statutory interpretation more frequently appears on lists of articles most cited by both judges and legal academics than scholarship on other topics); see also Gregory Scott Crespi, The Influence of a Decade of Statutory Interpretation Scholarship on Judicial Rulings: An Empirical Analysis, 53 SMU L. REV. 9, 11-14, $20-22$ (2000) (confirming conclusions of Merritt \& Putnam). But see Adam M. Samaha, Low Stakes and Constitutional Interpretation (draft Aug. 29, 2010), available at http://ssrn.com/abstract=1669381 (arguing that scholarly debates about constitutional interpretation have "low stakes," i.e., little likelihood of affecting adjudicated outcomes).
} 
scholarly efforts, and comfort with interdisciplinary work, the forms of bibliometric analysis used to study disciplinary structures outside law have rarely been trained on the legal field, and never by legal scholars.

The second half of the paper explores specific features of legal scholarship in a particular research area. Based on an original study of the 154 most-cited articles on general topics in legal interpretation published in American law reviews from the nineteenth century on, Part III begins with a description of the field. Two pieces, an 1893 article by James Bradley Thayer and an 1899 essay by Oliver Wendell Holmes, defined themes that have shaped the content and rhetorical tactics of the literature down to the present. Part III also examines two developments not anticipated in these pieces: the withering of interest in contract interpretation, at least described as such, after the 1960s, and the explosion, a few decades later, of interest in judicial deference to agency interpretations. Part IV focuses on features of the citation network created by the articles. These features support considering legal interpretation a coherent "interest area" but also suggest special, seldom-remarked peculiarities of the area. Among other things, the patterns disclosed by the network suggest that academics working in this area may not well understand the social and cultural dynamics of their efforts, and that as they respond to the institutional pressures inherent in their position, they erode their own claims to expertise in unexpected ways.

\section{The Debate Over the VAlue of ScholarshiP}

\section{A. A Brief Introduction to the Debate Over Legal Scholarship}

Academic law reviews, the primary publication outlet for the writing of law professors, emerged in something like their current form in the last few decades of the nineteenth century. ${ }^{3}$ Legal professionals and academics almost immediately questioned the value of their contents. By 1906, when the Index to Legal Periodicals cited a mere 60 sources (compared to 1,025 today), a commentator had already called the law review field "overcrowded" and noted that the

\footnotetext{
${ }^{3}$ On the emergence of law reviews, see especially Michael I. Swygert \& Jon W. Bruce, The Historical Origins, Founding, and Early Development of Student-Edited Law Reviews, 36 Hastings L.J. 739 (1985); see also Bernard J. Hibbitts, Last Writes? Reassessing the Law Review in the Age of Cyberspace, 71 N.Y.U. L. REV. 615 (1996).
} 
reviews published little of "interest" to most "practicing lawyers."4

The legal realists carried this critique through the first few decades of the twentieth century. The best-known realist-affiliated attack was Fred Rodell's 1930 article Goodbye to Law Reviews. ${ }^{5}$ Rodell emphasized the formality and narrow subject-matter of the articles published in law reviews, and his complaints were echoed by some judges, including Oliver Wendell Holmes. ${ }^{6}$ The same features criticized by Rodell, however, made at least some academic legal writing attractive to lawyers and judges. ${ }^{7}$ And over the first half of the twentieth century, judicial opinions cited law review articles more and more often. ${ }^{8}$ Celebrated examples of influential scholarship include Samuel D. Warren and Louis Brandeis’s 1890 article describing a legal right to privacy $^{9}$ and the Supreme Court's reliance, in the 1938 Erie Railroad v. Tompkins ${ }^{10}$ decision, on Charles E. Warren's study of an eighteenth-century statute to overrule a nearly century-old Supreme Court precedent. ${ }^{11}$

The nature of critiques of legal scholarship shifted later in the twentieth century. Some judges, defending legal scholarship, have continued to sound familiar themes regarding the

${ }^{4}$ Frederic C. Woodward, Editorial Notes, 1 ILL. L. REV. 39, 39 (1906), discussed in Howard Denemark, How Valid Is the Often-Repeated Accusation That There Are Too Many Legal Articles and Too Many Law Reviews?, 30 AKRON L. REV. 215, 217 (1996).

${ }^{5}$ Fred Rodell, Goodbye to Law Reviews, 23 VA. L. REV. 38 (1937).

${ }^{6}$ Charles E. Hughes described both Holmes's attitude and its eventual eclipse: “[T]hirty years ago Mr. Justice Holmes would refer somewhat scornfully to the 'notes' in law school reviews which ventured... to criticise pronouncements of the Supreme Court... . But ... there has been a growing regard for these 'notes' as helpful analyses of decisions.” Charles E. Hughes, Foreword, 50 YALE L.J. 737, 737 (1941).

${ }^{7}$ See id.; see also Benjamin N. Cardozo, Introduction to SELECTED READINGS ON THE LAW OF CONTRACTS From AMERICAN AND ENGLish LEgAL PERIODICALS ix (Assoc. of Am. L. Sch. ed., 1931) ("[L]eadership in the march of legal thought has been passing in our day from the benches . . to the chairs of universities. . . .”); Frederick Evan Crane, Law School Reviews and the Courts, 4 ForDHAM L. REV. 1, 1 (1935); Learned Hand, Have the Bench and Bar Anything to Contribute to the Teaching of Law?, 24 MiCH. L. REV. 466, 466, 467 (1926).

8 See, e.g., Douglass B. Maggs, Concerning the Extent to Which the Law Review Contributes to the Development of the Law, 3 S. CAL. L. REV. 181, 189 (1930); Chester A. Newland, Legal Periodicals and the United States Supreme Court, 7 U. KAN. L. REV. 477, 477 (1959); Robert Post, The Supreme Court Opinion as Institutional Practice: Dissent, Legal Scholarship, and Decisionmaking in the Taft Court, 85 MinN. L. REV. 1267, 1359-80 (2001) (discussing history of and shifts in Supreme Court citation of legal academic work).

${ }^{9}$ Samuel D. Warren and Louis D. Brandeis, The Right to Privacy, 4 HARV. L. REV. 193 (1890). On the influence of this article, see, e.g., Judith S. Kaye, One Judge's View of Academic Law Review Writing, 39 J. LEGAL EDUC. 313, 316 (1989).

10304 U.S. 64 (1938).

11 Charles E. Warren, New Light on the History of the Federal Judiciary Act of 1789, 37 HARV. L. REV. 49 (1923). For a discussion of the influence of Warren's article on Erie, see, e.g., Newland, supra note 8, at 481-82. A more recent example, almost as often noted, is the influence on due process doctrine of Charles A. Reich, The New Property, 73 YALE L.J. 733 (1964), discussed in, e.g., Erwin Chemerinsky, Why Write?, 107 MiCH. L. REV. 881,893 (2009). 
experimentation inherent in the system of production of this scholarship and the resulting wealth of ideas it may offer. ${ }^{12}$ But changes in the academy have made new kinds of skepticism possible. Increased self-awareness about interdisciplinary scholarship has generated dispute about the standards appropriate to the evaluation of legal scholarship and the extent to which interdisciplinary efforts by law professors remain "legal."13 And both interdisciplinary work and more traditional pieces focusing exclusively on legal doctrine appear to some critics to betray a growing disparity in interests and expertise between practicing lawyers and legal academics. ${ }^{14}$

Aided by machine-searchable databases, some legal scholars have also sought to justify their work in new ways, in particular by taking judicial citations of legal scholarship as a measure of the scholarship's value. In general, the findings of such studies support the critics of legal scholarship; in most respects, citations of legal scholarship by courts and by legal scholars follow different patterns, indicating that academics value different forms of scholarship than judges do. ${ }^{15}$ But judges and legal academics do tend to cite similar articles in certain subject areas, including legal interpretation, and specifically, statutory interpretation. ${ }^{16}$ The conventional explanation of this phenomenon ${ }^{17}$ is that on this topic (along with constitutional law topics), scholars' interest in theory ${ }^{18}$ converges with judges' and lawyers’ interest in principles directly

${ }^{12}$ See, e.g., Stanley H. Fuld, A Judge Looks at the Law Review, 28 N.Y.U. L. REV. 915, 916 (1953) (observing that "the 'fantastically non-utilitarian' law review type brief, exhaustive and analytical, affording a broad vista of the law, serves as a real aid to judicial decision”); Kaye, supra note 9, at 315; Alex Kozinski, Who Gives a Hoot about Legal Scholarship, 37 Hous. L. REV. 295, 295 (2000) (describing himself as “big fan of legal scholarship”).

${ }^{13}$ See, e.g., J.M. Balkin, Interdisciplinarity as Colonization, 53 WASH. \& LEE L. REV. 949 (1996); Philip C. Kissam, The Evaluation of Legal Scholarship, 63 WASH. L. REV. 221, 252-54 (1988); Edward L. Rubin, On Beyond Truth: A Theory for Evaluating Legal Scholarship, 80 CAL. L. REV. 889 (1992).

${ }^{14}$ See, e.g., United States v. \$639,558 in U.S. Currency, 955 F.2d 712, 722 (D.C. Cir. 1992) (Silberman, J., concurring) ("[M]any of our law reviews are dominated by rather exotic offerings of increasingly out-of-touch faculty members. ...”). See also Harry T. Edwards, The Growing Disjunction Between Legal Education and the Legal Profession, 91 Mich. L. REV. 34 (1992); Ellen A. Peters, Reality and the Language of the Law, 90 Yale L.J. 1193, 1193 (1981); Alvin B. Rubin, Does Law Matter? A Judge's Response to the Critical Legal Studies Movement, 37 J. Legal Educ. 307, 307-08 (1987); Patricia M. Wald, Teaching the Trade: An Appellate Judge's View of Practice-Oriented Legal Education, 36 J. LEGAL EDUC. 35, 73, 44 (1986) (expressing “worry about law reformers who do not know how the law works").

${ }^{15}$ Courts, for example, cite more articles on state law, fewer articles from critical legal studies perspectives, more articles from less elite reviews, and more articles from nonscholarly authors (practitioners, judges) than legal scholars do. Merritt \& Putnam, supra note 2, at 885-96.

${ }^{16}$ Id. at 802, 882-83. See also Crespi, supra note 2, at 11-14, 20-22.

${ }^{17}$ See Crespi, supra note 2, at 9-10; Merritt \& Putnam, supra note 2, at 882.

18 See, e.g., Michael J. Saks, Howard J. Larsen \& Carol J. Hodne, Is There a Growing Gap Among Law, Law Practice, and Legal Scholarship?: A Systematic Comparison of Law Review Articles One Generation Apart, 30 SUFFOLK L. REV. 353, 370 (1996) (concluding that law review articles have been growing increasingly theoretical 
applicable in legal reasoning. ${ }^{19}$ As the discussion below suggests, this explanation, while reasonable, fails to account for other troublesome features of the scholarship in this area.

\section{B. The Debate Over the Academy}

Many concerns about the value of legal scholarship parallel anxieties about the functions of higher education generally. These anxieties are as old as Western culture but assumed many of their modern characteristics in the twentieth century. ${ }^{20}$ The debate concerns the social function of the university, and more especially the legitimacy of academics' activities, including the scholarship they produce. It is largely carried on in instrumentalist terms: what norms should we use to assess the activities and output of universities and academics? And it is often structured around an opposition between a traditional set of disciplines and values associated with culture, the humanities, and the arts, on the one hand, and a more explicitly instrumental set of values associated with the sciences and applied technical fields, on the other.

The arts-sciences opposition in its current form is often credited to the English physicist and novelist C.P. Snow's mid-twentieth-century account of the "two cultures," which he identified with literary studies and the sciences. ${ }^{21}$ Snow lamented the "mutual incomprehension" between the two cultures, identified the sciences as the only site of genuine intellectual and social progress, and urged greater political support and resources for the development of the academic sciences. ${ }^{22}$ In a public debate with Snow, the Cambridge literary critic F.R. Leavis criticized Snow's identification of literary culture with political power and argued for the transformative power of the humanities. ${ }^{23}$

A series of analogous debates has played out in the United States over the second half of the twentieth century as the academy has weathered several bitter crises. In the 1960s, these

since the 1960s).

${ }^{19}$ See sources cited supra note 2; see also, e.g., Thomas L. Ambro, Citing Legal Articles in Judicial Opinions: A Sympathetic Antipathy, 80 AM. BANKR. L.J. 547, 547 (2006).

${ }^{20}$ See Gerard Delanty, Challenging Knowledge: The University in the Knowledge Society 1-11 (2001).

${ }^{21}$ C.P. Snow, The Two Cultures And a Second Look (1963). Snow originally delivered his lecture on the topic in 1959 at the University of Cambridge. For a discussion of the debate in context, see Guy Ortolano, Two Cultures, One University: The Institutional Origins of the "Two Cultures" Controversy, 34:4 ALBION 606 (2002).

${ }^{22}$ SNOW, supra note 21, at 4.

${ }^{23}$ See F.R. LEAVIS, THE SignifiCANCE OF C.P. SNOW (1962). 
crises mainly focused on university governance: who should have the power to allocate resources within the university? ${ }^{24}$ In the 1980s and 1990s, resource struggles were joined by challenges to the continuing validity of Snow's dichotomy, most visibly in the "canon wars" over the construction of new humanities curricula ${ }^{25}$ and the "science wars" over the legitimacy of the sciences considered from a humanistic perspective. ${ }^{26}$ In the last decade, the focus of debate has shifted back to resource allocation. As public support for higher education institutions has declined, the institutions have had to suspend or terminate departments; most often, the downsized departments have been humanities departments. ${ }^{27}$

These developments have prompted a great outpouring of critical commentary for a general audience. As Snow and Leavis did decades ago, academics and advocates have justified competing claims to resources by differentiating the activities of different groups within the academy, in part based on those groups' own descriptions of their activities, and attempting to show which have the best claims to social legitimacy. ${ }^{28}$ They have also sought to show that the university, as a whole, serves social functions distinct from those served by other institutions. ${ }^{29}$ Such arguments take different forms when made by or for groups within the academy-like law and business schools - that have direct links to professional groups in the non-academic society.

\section{Special Features of the Legal Academy}

Since the late nineteenth century, most American law schools have been situated within

${ }^{24}$ See, e.g., Walter P. Metzger, The Crisis of Academic Authority, 99:3 DAEDALUs 568 (1970); DELANTY, supra note 20 , at 2 .

${ }^{25}$ For an overview, see Rachel Donadio, Revisiting the Canon Wars, N.Y. TIMES, Sept. 16, 2007, available at http://www.nytimes.com/2007/09/16/books/review/Donadio-t.html.

${ }^{26}$ Prominent contributions from the Snow point of view were PAUL R. GROSS \& NoRMAN LEVITT, HIGHER Superstition: The AcAdemic Left And Its QuARrels With ScIEnCE (1994); Alan D. Sokal, Transgressing the Boundaries: Towards a Transformative Hermeneutics of Quantum Gravity, 46/47 SOCIAL TEXT 217 (1996) (offering scandalous spoof of humanistic critique of scientific work).

27 See, e.g., Budget-Cutting Colleges Bid Some Languages Adieu, N.Y. TIMES, Dec. 3, 2010, available at http://www.nytimes.com/2010/12/05/education/05languages.html.

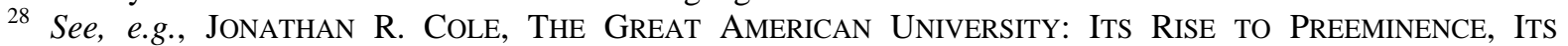
Indispensable National Role, Why It Must Be Protected (2010); Martha C. Nussbaum, Not For Profit: Why DEMOCRACY NEEDS THE HuMANITIES (2010).

${ }^{29}$ See, e.g., Stanley Aronowitz, The KnOWledge FACTORY: Dismantling the Corporate University AND CREATing True Higher LEARning (2001); DELANTY, supra note 20; LOUIS MENAND, ThE MARKETPLACE OF IDEAS: REFORM AND RESISTANCE IN THE AMERICAN UNIVERSITY (2010). 
institutions of higher education, but outside colleges of arts and sciences. ${ }^{30}$ So it is not surprising that debates about the purposes and value of higher education would be echoed in the law school context, even where they did not concern the legal academy directly. But because of the peculiar place of law schools in the academy and the society, discussions of the value of legal scholarship encounter unique problems.

American law schools most basically differ from schools of arts and sciences in that most of their students attend law schools specifically to be eligible for professional licensing. ${ }^{31}$ In addition, law school faculty have traditionally not been trained as academic professionals, but have received the same training as those students who become lawyers (although recent hiring trends may be eroding this tradition). ${ }^{32}$ And unlike other academics, law school faculty are expected to publicize their research largely through student-edited journals, rather than the peerreviewed journals common in other disciplines. ${ }^{33}$ As a result, decisions about which scholarship will be published, and where, are mostly made not by academics but by students in training to become non-academic professionals. ${ }^{34}$

Debate concerning this last practice shades easily into, and complicates, debates about the purposes of legal scholarship. If those purposes are understood to be primarily educational and instrumental — the education of law students ${ }^{35}$ and the persuasion of lawmakers and judges ${ }^{36}$ _

${ }^{30}$ See, e.g., Larry Alexander, What We Do and Why We Do It, 45 STAN. L. REV. 1885, 1885 (1992); Linda R. Crane, Interdisciplinary Combined-Degree and Graduate Law Degree Programs: History and Trends, 33 J. MARSHALL L. REV. 47, 53 (1999).

${ }^{31}$ See Albert J. Harno, Legal Education in the United States: A Report Prepared For the SurVEy of THE LEGAL PROFESSION 86-95 (1953).

${ }^{32}$ See, e.g., Chemerinsky, supra note 11, at 885; John H. Langbein, Scholarly and Professional Objectives in Legal Education: American Trends and English Comparisons, 2 PRESSING PROBLEMS IN THE LAW: WHAT ARE LAW SCHOOLS FOR? (1996).

33 See, e.g., Banks McDowell, The Audiences for Legal Scholarship, 40 J. LEGAL EDUC. 261,268 (1990); Deborah Rhode, Legal Scholarship, 115 HARV. L. REV. 1327, 1356 (2002); Ronald D. Rotunda, Law Reviews-The Extreme Centrist Position, 62 InD. L.J. 1, 1 (1986). For criticism of these practices, see, e.g., Richard A. Posner, Against the Law Reviews, LegAl AfF., Nov.-Dec. 2004, at 58; Natalie C. Cotton, Comment, The Competence of Students as Editors of Law Reviews: A Response to Judge Posner, 154 U. PA. L. REV. 951 (2006).

${ }^{34}$ Some believe that these decisions also determine which pieces will have the most impact. See, e.g., Merritt \& Putnam, supra note 2, at 889-90 (finding that scholars are more likely than courts to cite pieces that appeared in prestigious journals). But see Dennis J. Callahan \& Neal Devins, Law Review Article Placement: Benefit or Beauty Prize?, 56 J. LEGAL EDUC. 374, 375 (2006) (arguing that high-quality articles are cited regardless of the review’s prestige); Rotunda, supra note 33 , at 8 (similar).

${ }^{35}$ See, e.g., Rotunda, supra note 33, at 4.

${ }^{36}$ See, e.g., Bruce Ackerman, The Marketplace of Ideas, 90 YALE L.J. 1131, 1131 (1981); Edward L. Rubin, The Practice and Discourse of Legal Scholarship, 86 MICH. L. REV. 1835, 1850 (1988). 
then it makes sense to continue the tradition of student editing. If, on the other hand, law reviews are conceived as providing the primary outlet for legal academics' scholarship, and if that scholarship is thought of as analogous to the scholarship produced by academics in other parts of the university, the use of student editors as gatekeepers may come to seem problematic. ${ }^{37}$

Consensus on the functions of law reviews is elusive, in part, because of a more basic ambiguity in the law school's situation at the intersection of two heavily discursive professional systems: that of law and that of the academy. This positioning is reflected in the other institutional characteristics of American law schools and creates confusion about legal academics' role in the shaping of professional and cultural discourses, and about the status and purposes of legal scholarship. Traditional doctrinal scholarship, which largely treats the two professional systems involved as one, is characterized by a "unity of discourse” with professional legal discourse: doctrinal scholarship mimics the form, rhetoric, and normative purpose of legal advocacy and judicial opinions. ${ }^{38}$ But legal academics have been producing non-doctrinal scholarship, as well, at least since the early twentieth century. ${ }^{39}$ This type of scholarship, which can be called interdisciplinary, is modeled on the scholarship produced by non-legal academics, and it is not always clear what makes such scholarship specifically "legal." Surveying these practices, some have concluded that there really is no such thing as "legal scholarship,” but only professional legal discourse, on the one hand, and non-legal scholarship, on the other, each to be evaluated by the norms of a different professional system. ${ }^{40}$ Those who disagree, contending that a specifically "legal scholarship" does exist, remain divided about where such scholarship fits into the Snow universe-whether it is a humane discipline, ${ }^{41}$ a social science, ${ }^{42}$ or something else.

Unless these points are settled, defenses of the value of legal scholarship have little hope of succeeding. Practice alone seems unlikely to settle them. Not surprisingly, legal academics have drawn on a variety of scholarly resources in attempts to address the issue, including the

\footnotetext{
${ }^{37}$ See, e.g., Frederick Schauer, The Authority of Legal Scholarship, 139 U. PA. L. REV. 1002, 1007 n.17 (1991).

${ }^{38}$ Rubin, supra note 36, at 1859-60.

${ }^{39}$ See, e.g., Max Radin, Scientific Method and Law, 19 Cal. L. Rev. 164 (1931).

${ }^{40}$ This position has been noted by, e.g., Arthur D. Austin, Footnotes as Product Differentiation, 40 VAND. L. REV. 1131, 1132 n.4 (1987); Balkin, supra note 13, at 967; Rubin, supra note 36, at 1835.

${ }^{41}$ See, e.g., Rubin, supra note 13, at 962.

${ }^{42}$ See, e.g., Alexander, supra note 30, at 1900.
} 
vocabularies and structures of not just political and legal advocacy ${ }^{43}$ but also those of AngloAmerican philosophy, ${ }^{44}$ continental philosophy, ${ }^{45}$ cultural studies, ${ }^{46}$ qualitative sociology, ${ }^{47}$ and descriptive economics. ${ }^{48}$ Oddly, legal academics seem so far not to have consulted the considerable body of academic work on the social, institutional, and material features of scholarship systems. This is the focus of Part II.

\section{ACADEMIC INQUIRY AS A SOCIAL PHENOMENON}

Scholarly approaches to the study of academic practices have taken three main forms. The first approach, a conceptual one, borrows from (and contributes to) philosophical inquiry, especially the philosophy of science. In addition to Snow, this approach is associated with the work of Thomas S. Kuhn and those influenced by him. The other two approaches use methods associated with the social sciences: interpretive studies based on interviews or participantobserver fieldwork, and studies of the material records of scholarly work, especially their formal characteristics, sometimes called "bibliometrics."49 This Part discusses the relations among these three approaches, then considers the oddly limited scope of legal scholarship on textual practices in general and scholarly texts in particular.

\section{A. Social Science Accounts of Academic Inquiry}

1. Conceptual and Participant-Based Approaches

Most contemporary conceptual approaches to the study of the dynamics of academic

43 See, e.g., Ackerman, supra note 36, at 1131; Alexander, supra note 30, at 1898, Chemerinsky, supra note 11, at 886-93; David Hricik \& Victoria S. Salzmann, Why There Should Be Fewer Articles Like This One: Law Professors Should Write More for Legal Decision-Makers and Less for Themselves, 38 SuFFOLK L. REV. 761,764 (2005); Rotunda, supra note 33, at 2.

${ }^{44}$ See, e.g., Schauer, supra note 37.

45 See, e.g., Rubin, supra note 36; Pierre Schlag, The Politics of Form, 139 U. PA. L. REV. 801 (1991).

${ }^{46}$ See, e.g., Balkin, supra note 13.

${ }^{47}$ See, e.g., Meir Dan-Cohen, Listeners and Eavesdroppers: Substantive Legal Theory and Its Audiences, 63 U. COLO. L. REV. 569 (1992).

${ }^{48}$ See, e.g., Ackerman, supra note 36; George L. Priest, Triumphs or Failures of Modern Legal Scholarship and the Conditions of Its Production, 63 U. COLO. L. REV. 725 (1992); George L. Priest, The Growth of Interdisciplinary Research and the Industrial Structure of the Production of Ideas: A Reply to Judge Edwards, 91 MiCH. L. REV. 1929 (1993).

49 Fred Shapiro defined "bibliometrics" for a law-review audience as "studies which seek to quantify the processes of written communication.” Fred Shapiro, The Most-Cited Law Review Articles, 73 CAL. L. REV. 1540, 1541 n.8 (1985) (quoting 12 AM. REV. Info. SCI. \& TECH. 35 (1977)). See generally NicOLA DE BELLIS, Bibliometrics AND CitATION ANAlysis: From the SCIENCE CitATION INDEX TO CybERMETRICS (2009). 
inquiry acknowledge the influence of Thomas Kuhn's 1962 book The Structure of Scientific Revolutions. Kuhn questioned traditional understandings of the nature of scientific progress, like Snow's. Such progress, according to Kuhn, does not involve just the gradual accumulation of new information and techniques, building on previous insights, but also occasional "paradigm shifts” based on radically new conceptualizations of the world and our interaction with it. In the periods between such shifts, scientists engage in "normal science," expanding the applications of the currently dominant paradigms through "puzzle-solving.,

Kuhn's account has gained wide (though not universal) acceptance as an accurate and fruitful way of thinking about intellectual change in general. ${ }^{51}$ Although many legal academics are familiar with Kuhn and his basic ideas, ${ }^{52}$ they have not made much use of some of the elaborations of these ideas by others. Much Kuhn-influenced work has explored the social dimensions of particular paradigm shifts: the ways in which the reception and dissemination of scholarly ideas and their expressions are shaped by social as well as conceptual factors. The "science studies" school examines how specific scientific and technological changes depend on improbable convergences of political and economic resources, personal ties, and communication systems. $^{53}$ (This and similar work sparked the "science wars" mentioned earlier.) Sociologist Randall Collins has blended Kuhnian and other frameworks to explain the global development and recurrence of schools of philosophical thought as a matter of interpersonal ties and institutional settings. ${ }^{54}$

In recent decades, social scientists have increasingly studied these details of the social setting of academic work, and the relations among different types of academic work, through interviews, questionnaires, and participant observation. A good example is Tony Becher's

50 ThOMAs S. KuHN, The StruCture OF SCIENTIFiC ReVOlutions (1962).

51 See, e.g., Randall Collins, The Sociology of Philosophies: A Global Theory of Intellectual CHANGE 537 (1998).

${ }^{5}$ See, e.g., Charles W. Collier, Interdisciplinary Legal Scholarship in Search of a Paradigm, 42 DUKE L.J. 840 (1993); Richard Delgado, Norms and Normal Science: Toward a Critique of Normativity in Legal Thought, 139 U. PA. L. REV. 933 (1991); Rubin, supra note 13, at 957.

53 See, e.g., Michel Callon, Some Elements of a Sociology of Translation: Domestication of the Scallops and the Fishermen of St. Brieuc Bay, in Power, Action And Belief: A New Sociology of Knowledge 196 (John Law ed., 1986); Bruno Latour \& Steve WoOlgar, Laboratory LifE: The Social Construction OF SCIENTIFIC FACTS (1979).

${ }^{54}$ COLLINS, supra note 51, at 129. 
highly regarded 1989 study of “academic tribes and territories.”55 Based on interviews with 220 academics in the United Kingdom and United States, Becher proposed a taxonomy of disciplinary sub-institutions based on their characteristics along two dimensions, the cognitive and the social. Becher suggested that cognitively, disciplines are either predominantly "hard" (quantitative and cumulative, with research questions determined by available technologies) or "soft” (qualitative and controversial, less determined by technique) and either "pure” (selfregulating) or "applied” (regulated by outside interests). ${ }^{56}$ Socially, he described disciplines as either “convergent” (maintaining uniform standards and a stable elite) or “divergent” (marked by disputation and often valuing the unorthodox) and either "urban" (marked by intense communication among a small number of researchers, with quick resolution of mutually recognized problems) or "rural" (marked by more dispersed researchers and slower recognition and resolution of problems). ${ }^{57}$ Becher's study is valuable because it adds detail to Snow's "two cultures" taxonomy, allowing greater specificity about the position of law schools in the contemporary academy. In Becher's view (supported by Fiona Cownie's more recent work on legal academia in the United Kingdom), ${ }^{58}$ law as an academic discipline is cognitively unique in that it is soft and applied (the only other applied disciplines Becher identifies are pharmacology and engineering); ${ }^{59}$ socially, it is divergent ${ }^{60}$ and rural. ${ }^{61}$ Interestingly, considered under Becher's scheme, law as a profession would seem to bear different characteristics; indeed, as a profession, Western law might be considered the paradigmatic "convergent” discourse. ${ }^{62}$

One limitation of Becher's work is that it presents a snapshot of academic “tribes” at a moment in time and does not try to explain why a variety of disciplinary cultures might originally have developed. Others have tried to do so. Sociologist Andrew Abbott, for example, has argued that the social and cultural conditions present in the late nineteenth-century United

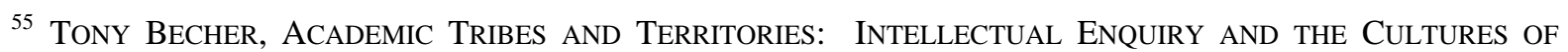
DISCIPLINES (1989).

${ }^{56}$ Id. at $152-71$.

${ }^{57}$ Id.

${ }^{58}$ Fiona CoWnie, Legal ACAdEMiCs: Culture AND IDENTITIES (2004).

${ }^{59}$ BECHER, supra note 55, at 155.

${ }^{60}$ Id. at 156.

${ }^{61} \mathrm{Id}$. at 158.

${ }^{6}$ Cf. David Mellinkoff, The Language of the Law (1963); Elizabeth Mertz, The Language of the LAW: LEARNING TO “THINK LIKE A LAWYER” (2007). 
States generated the constellation of arts and sciences disciplines that still structure the American university-and that concerns about overspecialization and the need for interdisciplinary conversations are just as old as this arrangement. ${ }^{63}$ (Abbott does not analyze law schools, but it would appear that the same is true of them.) Abbott attributes this stability to academic hiring practices and more basic social psychological dynamics. But according to him, this institutional stability breeds conceptual dynamism: within each discipline, and among them, other pressures, including the logical consequences of the division of labor in any sphere, the drive to seek status, and competition for resources, impel an "endlessly proliferating lineage structure” of academic subspecialties, which Abbott describes as "fractal" in shape. ${ }^{64}$ Drawing on his own prior work on the sociology of professions, Abbott notes that “differentiation[] along the lines of 'purity' is quite general to knowledge-based occupations,” like academia; “specialists . . . tend to withdraw into pure work," particularly when their authority or expertise is challenged by others. ${ }^{65}$ This tendency is true of both academic professionals and other professionals, including lawyers. ${ }^{66}$

\section{Network and Bibliometric Approaches}

According to Abbott, academics are under constant pressure to "find[] new areas of things to know," and they do so by "rearrang[ing their] fractal allegiances,” redefining and recombining conceptual and rhetorical distinctions previously drawn within and between disciplines to justify the continuing division of academic labor. ${ }^{67}$ A good example of this kind of bridge building in the academy is the study of network properties, which draws upon a variety of traditional fields of inquiry and has "exploded across the academic spectrum" over the past several decades. ${ }^{68}$ Early on, those studying networks turned their attention to networks of communications, including the networks formed by citation references in academic publications. The study of large networks of this kind was assisted by the creation, in the 1960s, of machine-

${ }^{63}$ ANDREW ABBOtT, ChAOS OF DisCiPLINES 122 n.1, 122-26, 136 (2001).

${ }^{64}$ Id. at $130,147-52$.

${ }^{65} \mathrm{Id}$. at 22; see also id. at 146-47.

${ }^{66}$ See Andrew AbBott, The System of Professions: An Essay in the Division of ExPert Labor 8-9 (1988).

${ }^{67}$ Id. at $230-31$.

${ }^{68}$ Duncan J. Watts, The "New" Science of Networks, 30 Annual ReV. OF Sociology 243, 243 (2004). On the

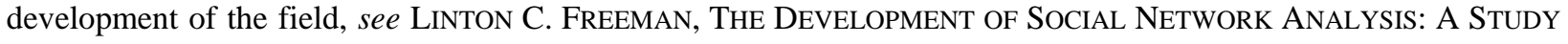
IN THE SOCIOLOGY OF SCIENCE (2004). 
searchable periodicals indexing databases modeled on the Shepard's citation system familiar to lawyers since the late nineteenth century. ${ }^{69}$ But despite the filial relation between legal text practices and this area of academic research, many legal academics are unfamiliar with some of the central developments in the field.

A pivotal figure in the study of academic citation networks was the physicist and information scientist Derek de Solla Price. ${ }^{70}$ In 1965 Price published an analysis of several “citation summaries” of publications in scientific journals, assessing patterns in the frequency with which the publications cited earlier publications in the population. ${ }^{71}$ One of his enduring findings was that citation practices follow power laws, that is, a very small number of papers receive the vast majority of citations from later papers. ${ }^{72}$ Considering the shifts in the identity of heavily cited papers over time, Price coined the term "research front" to describe their significance and suggested that "it is the existence of a research front, in this sense, that distinguishes the sciences from the rest of scholarship."73 As this language indicates, Price was writing within a paradigm inspired by Snow's dichotomy and vision of science as cumulative. ${ }^{74}$

Other scholars, discussed below, have developed Price's speculations about the possibility of differentiating among disciplines based on the patterns of citation in their literatures. In his own later work, Price focused mainly on identifying additional general principles. One was the phenomenon of "cumulative advantage processes," or the principle "that success seems to breed success," which, Price contended, applies across scholarly areas. ${ }^{75}$ In this work, Price showed that citation frequencies are determined not by the contents of cited works so much as "the past history of the cited paper; ... citations are generated by a pull mechanism

\footnotetext{
69 See Shapiro, supra note 49, at 1540-42.

${ }^{70}$ On the impact of Price's work, see M.E.J. Newman, The Structure and Function of Complex Networks, 45 SIAM REV. 167, 176, 186-88, 213-15, 220 (2003).

${ }^{71}$ Derek J. de Solla Price, Networks of Scientific Papers, 149 SCI. 510, 510 (1965).

${ }^{72} \mathrm{Id}$. at 511. For an explanation of power-law distributions and scale-free networks, see Watts, supra note 68, at 250-51. On the ubiquity of naturally occurring power-law distributions and scale-free networks, see also David G. Post \& Michael B. Eisen, How Long Is the Coastline of the Law? Thoughts on the Fractal Nature of Legal Systems, 29 J. LEGAL STUD. 545, 569-70 \& n.37 (2000).

${ }^{73}$ Price, supra note 71 , at 512.

${ }^{74}$ See id. at 515.

75 Derek J. de Solla Price, A General Theory of Bibliometric and Other Cumulative Advantage Processes, 27 J. AM. SOC’Y FOR INFO. SCI. 292 (1976).
} 
from previous citation rather than from a push mechanism of the papers that do the citing."76 Citation frequency counts reflect the circumstances surrounding the generation and especially the past scholarly treatment of particular scholarly efforts. ${ }^{77}$ This does not mean frequency counts are meaningless; they might not measure merit, but they are "a rough measure of the writings which have had the most extensive impact."78 Thus, this principle supports, at the level of concrete textual features, the Kuhn-derived analysis of the social determinants of intellectual change. The cumulative advantage principle, together with the power-law distribution of citations, also led Price to develop the notion of "invisible colleges,"79 defined as "the hierarchical elite resulting from an expectable inequality" produced by these two principles. ${ }^{80}$ Elites of this kind exhibit "total undemocracy," according to Price, but are not caused by deliberate domination; "the phenomenon is ... a mechanism thrown up automatically by the scientific community."

Others have pursued the implications of Price's hints at a taxonomy of disciplinary citation practices. One of the most comprehensive such studies, by Lowell Hargens, compared scholarly citation networks in seven research areas to test Price's hypothesis that disciplinary reference patterns tend to fall into two forms: ${ }^{82}$ a research-front model, which "focus[es] on recently published research while tending to ignore foundational work" ${ }^{\text {}}$ and corresponds to Kuhn's normal science and Becher's hard and convergent disciplines, and a model of work that

${ }^{76}$ Id. at 304-05.

${ }^{77}$ For a parallel account of legal citation practices that does not cite Price or use similar methods, see J.M. Balkin \& Sanford Levinson, How to Win Cites and Influence People, 71 ChI.-KenT L. Rev. 843, 845 (1996) (describing "citation practices a[s] a sort of economy of communication and exchange between academics, or ... an ecology of reproduction and hence competition with other citations").

${ }^{78}$ Fred R. Shapiro, The Most-Cited Articles from the Yale Law Journal, 100 YALE L.J. 1449, 1543-54 (1991) [hereinafter Shapiro, Yale].

${ }^{79}$ See DereK J. De Solla Price, Little Science, Big Science (1963); Derek J. de Solla Price, Some Remarks on Elitism in Information and the Invisible College Phenomenon in Science, 22 J. Am. Soc'y for Info. Sci. 74 (1971) [hereinafter Price, Remarks]. See also Diana Crane, Invisible Colleges: Diffusion of KnOWledge in SCIENTIFIC COMMUNITIES (1972).

${ }^{80}$ Price, Remarks, supra note 79 , at 75.

${ }^{81} I d$.

${ }^{82}$ Lowell L. Hargens, Using the Literature: Reference Networks, Reference Contexts, and the Social Structure of Scholarship, 65 AM. Soc. REV. 846, 849 \& n.7 (2000). The seven fields were celestial masers, an astronomy research area; chiral separations, a chemistry research area; light-front physics, a theoretical nuclear physics research area; literary criticism on the works of Toni Morrison, an American literature research area; organizational population ecology, a sociology research area; rational expectations, an economics research area, and the Stroop effect, a psychology research area. Id. at 850 \& Table I.

${ }^{83}$ Id. at 846. 
tends to "pursue questions raised in classic texts or exegesis" ${ }^{84}$ of those texts, associated with Becher's soft and divergent disciplines. ${ }^{85}$ Hargens’s study, echoing Becher’s qualitative approach to the relations among disciplines, suggested that Price's dichotomy was too basic. While papers on natural science subjects do cite recently published work more often than papers on humanities and behavioral science subjects do, ${ }^{86}$ Hargens found that behavioral science papers (especially on rational expectations theory), not humanities papers, most overcited foundational papers. ${ }^{87}$ Hargens was not certain of the explanation for these patterns, but he did note that they might result from the different social characteristics of different fields: in convergent or urban fields, the need to cite foundational works should decrease for the duration of consensus, since authors will not need to convince readers of the significance of their contributions. $^{88}$ This explanation was consistent with Hargens's finding that scholars in different areas used citations differently within their work. In fields in which authors overcited foundational papers, they also used more “orienting research lists” (similar to what lawyers know as string cites) to "provide a framework for their work and imply that the framework constitutes an acknowledged scholarly position,” as well as “a legitimate approach.”89

Although the focus of this study is on citation patterns, not all systematic analysis of the material records of scholarly work has focused on citation networks. Academics have also analyzed patterns in the content of scholarly publications and have found disciplinary differences in this dimension as well. ${ }^{90}$ Work of both kinds validates some intuitions and conclusions reached by other methods, but it also supplies detail unavailable to other models of research and

\footnotetext{
${ }^{84} I d$.

${ }^{85}$ Earlier, Charles Bazerman proposed that scholars working in more contested fields, such as political science, would overcite foundational sources; lacking “a theory that could provide a 'consistent rhetoric' for their research, authors [would be] forced to construct justifications that 'reassemble, reinterpret, and discuss anew wide ranges of the literature, dating back into the discipline's history.”' Hargens, supra note 82, at 857 (quoting CHARLES Bazerman, Shaping Written KnOWledge: The Genre And ACtivity of the Experimental Article in SCIENCE 283 (1988)).

${ }^{86}$ Hargens, supra note 82, at 850-54.

${ }^{87}$ Id. at 854 .

${ }^{88} \mathrm{Id}$. at 856 .

${ }^{89}$ Id. at 858. The fields exhibiting both increased use of "orienting research lists" and overcitation of foundational papers were the three behavioral science areas Hargens studied (organizational population ecology, rational expectations, and the Stroop effect). In the humanities area, both citations to foundational papers and orienting research lists were absent.

90 See especially Susan PeCK MacDonald, Professional Academic Writing in the Humanities and SOCIAL SCIENCES (1994).
} 
can produce surprising information. Although the questions this kind of work can answer are limited in scope, they are not limited by research area; there is no reason to think similar approaches might not be fruitfully applied to legal scholarship.

\section{B. The Analysis of Text Networks in Legal Scholarship}

Given legal academics’ long traditions of self-scrutiny and self-defense, as well as their longstanding tendency to borrow from other disciplines, it is surprising that no legal academics have drawn on studies of textual practices to clarify their tasks and distinguish their work from that of other academics, on the one hand, and lawyers, on the other. Legal academics have indeed recognized the pertinence of citation analysis to their field (and even to their understanding of their own work), but they have neglected the kind of work done by scholars like Price and Hargens. ${ }^{91}$ This Part explores the limitations of the ways legal academics have considered their own textual practices.

First-year law students quickly learn that text networks, as embodied in citations, are crucial to the legal system. As Fred Shapiro has noted, “[l]inks between documents . . . are more important in law than in any other discipline. .. . In judges' opinions . . ., citation links ... are more significant than the words that surround the citations."92 It is natural, then, that citation practices within legal texts, especially judicial opinions, would have become a subject of interest to legal scholars. They have studied patterns of judicial citation of prior judicial precedent ${ }^{93}$ and patterns of judicial citation of other sources, including scholarly materials. ${ }^{94}$ Anxieties about the value and purposes of legal scholarship have led to comparisons, already mentioned, of the ways

\footnotetext{
${ }^{91}$ For example, in the first of his series of articles on the most-cited law review articles, Fred Shapiro mentioned several leaders of the field, including Eugene Garfield, Kenneth Clark, and Jonathan and Stephen Cole, but not Price. Shapiro, supra note 49, at 1541-43.

92 Fred R. Shapiro, The Most-Cited Law Review Articles Revisited, 71 CHICAGo-KenT L. REV. 751,752 (1996) [hereinafter Shapiro, Revisited].

93 See, e.g., William M. Landes, Lawrence Lessig \& Michael E. Solimine, Judicial Influence: A Citation Analysis of Federal Courts of Appeals Judges, 27 J. LEGAL STUD. 271 (1998).

94 See, e.g., Richard A. Mann, The Use of Legal Periodicals by Courts and Journals, 26 JURIMETRICS J. 400 (1986); Merritt \& Putnam, supra note 2; Michael D. McClintock, The Declining Use of Legal Scholarship by Courts: An Empirical Study, 51 OKLA. L. Rev. 659 (1998); Louis J. Sirico, Jr. \& Jeffrey B. Margulies, The Citing of Law Reviews by the Supreme Court: An Empirical Study, 34 UCLA L. REV. 131 (1986); Louis J. Sirico, Jr., \& Beth A. Drew, The Citing of Law Reviews by the United States Courts of Appeals: An Empirical Analysis, 45 U. MiAmI L. REV. 1051 (1991).
} 
that judicial opinions and other legal scholarship cite law review articles. ${ }^{95}$ In both areas, citation patterns follow the power law identified by Price ${ }^{96}$ and seem unrelated to the quality of the cited materials, however that quality might be evaluated, echoing his "cumulative advantage" principle. $^{97}$ In at least some areas, too, legal academics have observed the formation of “invisible colleges,” although, again, they do not follow Price’s account of the phenomenon. ${ }^{98}$

Legal scholars have explicitly recognized that citation analysis offers "grist” for “a sociology of legal scholarship."99 But although they seem eager to study networks of legal texts, they have produced few detailed studies of text networks within legal scholarship itself. ${ }^{100}$ There is a tinge of embarrassment to legal academics' work on scholarly citation practices, which has mostly been limited to examining and comparing the numbers of citations individual articles receive. ${ }^{101}$ In fact, the most sophisticated studies of textual practices in legal scholarship to date have been produced not by legal academics but by scholars in other fields: journalism, communications, and rhetoric.

The only study of legal scholarship to draw on Price's work in particular compared citation patterns in law review articles addressing media law with patterns in work on the same topic published in media and communications studies journals. ${ }^{102}$ The authors found that "law review citations [tend to be to more] recent materials, while citations in mass communication

95 See, e.g., Ian Ayres \& Frederick E. Vars, Determinants of Citations to Articles in Elite Law Reviews, 29 J. Legal STUD. 427 (2000); William M. Landes \& Richard A. Posner, Heavily Cited Articles in Law, 71 CHI.-KENT L. REV. 825 (1996); Mann, supra note 94; Merritt \& Putnam, supra note 2; Peter H. Schuck, Legal Complexity: Some Causes, Consequences, and Cures, 42 DuKE L.J. 1, 38 n.150 (1992); Shapiro, supra note 49; Shapiro, Yale, supra note 78; Shapiro, Revisited, supra note 92.

${ }^{96}$ See, e.g., Sirico \& Drew, supra note 94, at 1058-60 (showing predominance of citations to three law reviews and to recent articles in circuit court memorandum opinions); Merritt \& Putnam, supra note 2, at 888, 899-908.

${ }^{97}$ See, e.g., Balkin \& Levinson, supra note 77, at 846; Alfred L. Brophy, The Signaling Value of Law Reviews: An Exploration of Citations and Prestige, 36 FlA. ST. U. L. REV. 229, 238 (2009); Ronen Perry, The Relative Value of American Law Reviews: Refinement and Implementation, 39 CoNN. L. REV. 1, 3, 4, 34 (2006).

98 See especially Richard Delgado, The Imperial Scholar: Reflections on a Review of Civil Rights Literature, 132 U. PA. L. REV. 561, 563, 566 (1981) (concluding, based on “informal sociogram,” i.e., social-network diagram, of citations in high-profile scholarship on civil rights, that "mainstream writers [in this area] tend to acknowledge only each other's work").

99 Shapiro, Yale, supra note 78, at 1457.

100 See, e.g., Ayres \& Vars, supra note 95, at 427-28.

${ }^{101} \mathrm{Id}$. at 447 ("Citations analysis . . . unavoidably has a gossipy and at times tawdry aspect. We are drawn to citation rankings . . . but we are simultaneously repulsed by them . . .”). See also Brophy, supra note 97, at 232; Rubin, supra note 13, at 936.

${ }^{102}$ See Yorgo Pasadeos, Matthew D. Bunker, \& Kyun Soo Kim, Influences on the Media Law Literature: A Divergence of Mass Communication Scholars and Legal Scholars?, 11 COMM. L. \& POL'Y 179 (2006). 
journals are to much older publications" and that "mass communication scholars cite their law school colleagues often, but citations in the opposite direction are much less frequent."103 They hypothesized that legal scholarship might more generally tend to be more cumulative-akin to the scientific work produced during periods of normal science-than communications scholarship, ${ }^{104}$ or, alternatively, that "mass communication media law scholars are engaged in a somewhat more theoretically grounded enterprise that focuses more on the big questions in media law jurisprudence.”105 A more recent study of textual practices in law review writing reached some similar conclusions. ${ }^{106}$ This analysis of grammatical and rhetorical features of law review pieces on a particular topic (the arbitrability of claims by nonparties to arbitration agreements) found that the pieces seemed to resemble behavioral science scholarshipespecially "literature reviews"-more than humanities scholarship. ${ }^{107}$

No legal academic seems to have made comparable use of the analysis of textual practices in legal academic work. ${ }^{108}$ This might be just happenstance-maybe no legal academic has been well positioned to make this integration. Or it might be a matter of the difficulties of identifying boundaries between research areas in law; many of the most interesting analyses of the material records of academic work take a comparative approach, but such an approach requires consensus on the units to be compared. Departmental divisions in universities provide a natural focal point, but American law schools lack any analogous internal institutional feature. ${ }^{109}$ It cannot be, however, that legal academics have neglected these approaches because they are irrelevant to legal academics’ concerns. Legal academics' work is at least as much constituted by citation networks as that generated by other academics. And plenty of legal academics have speculated about the social and institutional determinants of legal scholarship; they have just

${ }^{103} \mathrm{Id}$. at 179.

${ }^{104}$ Id. at 194.

${ }^{105} \mathrm{Id}$. at $195-96$.

106 See Douglas M. Coulson, Legal Writing and Disciplinary Knowledge-Building: A Comparative Study, 6 J. Ass'N OF LEGAL WRITING DIRECTORS 160 (2009).

${ }^{107}$ Id. at $191-92$.

${ }^{108}$ Edward Rubin has opined that "legal articles . . . . do not display that higher degree of internal structure that characterizes many other academic fields, and that would be recognized as a cumulative tradition,” Rubin, supra note 36 , at 1885, but he does not seem to have based this conclusion on systematic study of the features of legal scholarship.

${ }^{109}$ For example, the Ayres-Vars study relied on the subject-matter categories of the Wilson Index to Legal Periodicals, but these categories do not map onto those used by Merritt and Putnam or by Crespi to determine that articles on statutory interpretation were among the most cited. Ayres \& Vars, supra note 95, at 432 n.21, 438 , 448. 
tended to draw on different disciplines to do so, and to focus on the scholarship's content, themes, and format, instead of its other textual features. ${ }^{110}$ The neglect of these approaches in legal self-scrutiny probably has more to do with the fact that they have been developed in relatively low-status academic specialties. Legal scholars tend to borrow from other disciplines to enhance the claim of their own work to serious scholarly status, and the current disciplinary status hierarchy privileges the pure, hard disciplines over others. ${ }^{111}$ While bibliometrics and citation analysis are cognitively hard, they are also associated with issues that have a decidedly “applied” status within law schools - the details and mechanics of academic and professional textual practices.

Somewhat inconsistently, legal academics are quite interested in the textual practices of judges and other nonacademic powerholders and seem to accord relatively high status to the detailed analysis of these practices. ${ }^{112}$ In this area, legal academics have long recognized_and capitalized on-the functional overlap between academic professionalism and legal professionalism, both of them areas in which the principal forms of expertise concern the processing and generation of texts. This overlap may partly explain why legal scholarship in this area seems relatively immune to anxieties about the value and purposes of legal scholarship. Academics in any discipline have expertise in the analysis and generation of texts, so their statements on that subject appear inherently valuable. ${ }^{113}$ And because so much of what lawyers and judges do involves texts, scholarship addressing such practices would seem to be an easy "sell" to those who have to try to solve textual puzzles-justifying their solutions by reference to other texts-on the ground. ${ }^{114}$ If legal scholarship on the subject of interpretation has a special status, then, it may be as much a product of blindness to and elision of the conditions of that scholarship's production as of a convergence of interests and objectives. The next two Parts of

110 See supra notes 43-48 and accompanying text.

${ }^{111}$ See COWNIE, supra note 58, at 64; see also supra note 27 and accompanying text.

112 See sources cited supra notes 92-99.

113 See, e.g., Rubin, supra note 36, at 1846.

${ }^{114}$ See, e.g., Edward L. Rubin, What Does Prescriptive Legal Scholarship Say and Who Is Listening to It? A Response to Professor Dan-Cohen, 63 U. CoLO. L. REV. 731, 742 (1992) ("The proper role of legal scholars is to speak to the communicative elements in judges' overall behavior. When the judge is trying to interpret a text ..., the prescriptions of legal scholars become relevant and useful. They are relevant because prescriptions about proper interpretation of a legal text or proper explanations of judicial reasoning are within the specific competency of scholars.”). 
this article explore the expressions and implications of these possibilities in scholarship on legal interpretation published in American law reviews since the 1890s.

\section{THE PATHS OF LEGAL INTERPRETATION SCHOLARSHIP}

This Part and the next are based on a study of the 154 most-cited articles on general topics in legal interpretation published in American law reviews between the late nineteenth century and the present. ${ }^{115}$ This Part considers the content and themes of some of this work; the next considers the citation network generated by the articles.

\section{A. Progenitors: Thayer and Holmes}

The two earliest pieces in the group are James Bradley Thayer's 1893 article The Origin and Scope of the American Doctrine of Constitutional Law ${ }^{116}$ and Oliver Wendell Holmes's 1899 essay The Theory of Legal Interpretation. ${ }^{117}$ Together, these pieces established a lasting framework for scholarship on legal interpretation. Thayer's article addresses a narrow question but identified a number of issues that still await resolution; Holmes's addresses a broader topic but offered no specific prescription. Although neither piece had the direct impact on legal doctrine of the Brandeis-Warren or Charles Warren articles, both have been cited an unusually large number of times in judicial decisions as well as subsequent scholarship. The relative popularity of the pieces in these two arenas, however, suggests an unexpected configuration of interests.

The "doctrine of constitutional law" mentioned in Thayer's title is the practice of judicial review of the constitutionality of legislative enactments. ${ }^{118}$ Thayer's article is best known for its

115 See Appendix A. The articles in the list include studies of interpretive practice and authority, as well as analyses of the role of interpretation in legal reasoning and defenses or critiques of particular interpretive methods. They also include articles focusing on specific categories of legal texts (such as contracts, constitutions, and statutes), specific interpreters, and specific interpretive principles. But they do not include articles focusing on the meaning of specific legal texts or on specific doctrinal areas, such as the interpretation of environmental statutes. The list was compiled from a list of the articles published in American law reviews, indexed in Hein Online, containing the word “interpretation,” cited more than 100 times (by Hein Online’s count), and fitting the criteria just described. Hein Online was used because of the historical coverage of its law review database.

116 James Bradley Thayer, The Origin and Scope of the American Doctrine of Constitutional Law, 7 HARV. L. REV. 129 (1893).

${ }^{117}$ Oliver Wendell Holmes, The Theory of Legal Interpretation, 12 HARV. L. REV. 417 (1899).

${ }^{118}$ As Thayer put it, this doctrine "allows to the judiciary the power to declare legislative Acts unconstitutional, 
articulation of a standard of near-total judicial deference to the constitutionality of legislative action. Thayer argues that any power that courts might have to review the constitutionality of legislation has important limitations, which Thayer infers from the implied powers granted to the legislature to "interpret" the Constitution in the process of its enactment of laws:

it is the legislature to whom this power is given,- - this power, not merely of enacting laws, but of putting an interpretation on the constitution which shall deeply affect the whole country, enter into, vitally change, even revolutionize the most serious affairs.... It is plain that where a power so momentous as this primary power to interpret is given, the actual determinations of the body to whom it is intrusted are entitled to a corresponding respect. . . ${ }^{119}$

Thayer's characterization of the legislature's "power to interpret” as awesome and potentially threatening contrasts with what he describes as the "pedantic and academic" nature of workaday legal interpretation by judges:

The court's duty, we are told [by those defending a plenary power of judicial review], is the mere and simple office of construing two writings and comparing one with another, as two contracts or two statutes are construed and compared when they are said to conflict; of declaring the true meaning of each ... an ordinary and humble judicial duty, as the courts sometimes describe it.... [Judicial review so conceived involves] a pedantic and academic treatment of the texts of the constitution and the laws. ${ }^{120}$

This basic distinction between legislative interpretation of the constitution and judicial interpretation of other legal texts is the core of Thayer's argument for judicial restraint. ${ }^{121}$ Ordinary legal interpretation involves an effort to "ascertain or apply [the] true meaning” of a text, an area in which judges have expertise, if of a "humble" sort. Judicial review, in contrast, concerns "whether legislation is sustainable or not," not the "true meaning of the constitution.",122 According to Thayer, judges have the capacity_-perhaps — to make the former kind of judgment, but not the latter, partly because no such "true meaning” really exists: "the constitution often admits of different interpretations; .... the constitution does not impose on the legislature any

and to treat them as null.” Thayer, supra note 116, at 129.

${ }^{119} I d$. at 136.

${ }^{120} I d$. at 138 .

${ }^{121} \mathrm{Id}$. at 143-44 ("If [the courts'] duty were in truth merely and nakedly to ascertain the meaning of the text of the constitution and of the impeached Act of the legislature, and to determine, as an academic question, whether in the court's judgment the two were in conflict, it would ... be an elevated and important office ... but yet a function far simpler than it actually is.”); see also id. at 139, 141, 150, 151.

${ }^{122} I d$. at 150. 
one specific opinion, but leaves open [a] range of choice.”123 By distinguishing judicial from legislative interpretive expertise in this way, Thayer avoided addressing the question that has vexed many subsequent lawyers and judges, including Holmes: to what extent do all legal texts “admit[] of different interpretations”? Later writers have also continued to wrestle with questions directly raised by Thayer, such as the scope of legislative supremacy, as well as with themes implicit in his argument, especially his ambivalent characterization of interpretation as simultaneously awesome and petty. ${ }^{124}$

In the seven years between the publication of Thayer's article and Holmes's, the Supreme Court cited a law review article for the first time in an opinion. ${ }^{125}$ And at the time Holmes' short piece appeared, he had been serving on the bench of the Supreme Judicial Court of Massachusetts for seventeen years. Despite Holmes’s presumably practical perspective, his chief topic in this piece was highly abstract: the determinacy of meaning of words in legal documents. Holmes distinguished between meaning in theory and meaning in practice in a way that recalls Thayer's distinction between judicial and legislative interpretation: "It is true that in theory any document purporting to . . have some legal effect has one meaning and no other ... . It is not true that in practice ... a given word or even a given collocation of words has one meaning and no other.”126 But Holmes had more to say about the nature of interpretation than Thayer had; Holmes described the process as based on the interpreter's understanding of "the general usages of speech" and as a matter of surrendering to "whatever galvanic current may come from the rest of the instrument.”"127 Holmes's focus on meaning in practice as a function of usage is the core of his objective theory of meaning, the point for which this article is best known. An important implication of the theory is that interpretation requires no special expertise beyond familiarity with linguistic usage. Thus, Holmes presented the theory as applicable to the interpretation of all kinds of legal documents; while "[d]ifferent rules might conceivably be laid down for the construction of different kinds of writing," "in fact we do not deal differently with a statute from

${ }^{123}$ Id. at 144; see also id. at 150 (“[A] court cannot always, and for the purpose of all sorts of questions, say that there is but one right and permissible way of interpreting the constitution.”).

${ }^{124}$ Id. at 156 n.1 (citing 1 Bryce, Am. Com., 1st ed., 377).

125 See McClintock, supra note 94, at 666 (discussing earliest Supreme Court citation of law review article in United States v. Trans-Missouri Freight Ass’n, 166 U.S. 290 (1897) (citing Amasa M. Eaton, On Contracts and Restraint of Trade, 4 HARV. L. REV. 128, 129 (1890))).

${ }^{126}$ Holmes, supra note 117 , at 417.

${ }^{127}$ Id. 
our way of dealing with a contract." ${ }^{128}$ This conception of interpretation, however, presented a paradox: if interpretation was the simple yet ineffable phenomenon Holmes claimed it was, did it need to be (or could it be) theorized at all? Holmes concluded his piece by suggesting that it did, but his explanation was less than detailed:

It may be, after all, that the matter is one in which the important thing, the law, is settled, and different people will account for it by such theory as pleases them best... B But although practical men generally prefer to leave their major premises inarticulate, yet even for practical purposes theory generally turns out the most important thing in the end. I am far from saying that it might not make a difference in the old question to which I have referred. ${ }^{129}$

Holmes's quandary anticipates contemporary anxieties about the purposes and value of legal scholarship. ${ }^{130}$ Should it present the arguments that judges would make, if they only had time, ${ }^{131}$ or should it do something else-and if so, what? Holmes's consideration of, and inability to answer, this question, along with his highly abstract theme, affected later use of his piece by legal academics and professionals.

While Thayer assumed that diverse constitutional meanings were possible, his main point was that judicial practices must be restrained; the Constitution tells us that it is the legislature that is the expert on which of its acts are consistent with the document's commands. Holmes's point was the reverse: because meaning is stabilized by usage, all judges have interpretive expertise, as lawyers do too, and we do not need to worry too much about checking judicial statements about the meaning of texts. This is the most fundamental contrast between the two pieces, and it marks out a polarity that still structures discussion. Yet even though Thayer seemed to offer a more explicit formula for judicial decision making, Holmes's article has been cited in nearly three times as many judicial opinions as Thayer's. ${ }^{132}$ Courts cite Holmes primarily to support assertions about the plain meaning of legal text. The popularity of the pieces among academics is the reverse. ${ }^{133}$ This suggests that commentators are more interested

${ }^{128}$ Id. at 419. Holmes also maintained that the same principles applied to the interpretation of wills. Id.

${ }^{129} \mathrm{Id}$. at 420 .

130 See supra note 6.

131 See, e.g., Hricik \& Salzmann, supra note 43, at 778-79.

132 Holmes's piece has been cited 62 times in judicial opinions, Thayer's 23 times. Search run on "thayer /s scope /s 129" and "holmes /s theory /s 417” in Westlaw ALLCASES database on Dec. 14, 2010.

133 Thayer's article has been cited 746 times in commentary since its publication; Holmes's has been cited only 306 times. 
than courts in formulas conducive to limiting the scope of judicial authority, and less interested in confirming their own self-conscious reflections on what it is they are doing. Since legal academics are engaged in a normative, interpretive activity that is superficially similar to judges’ activities, these academics have an interest in describing judicial power as limited and asserting their own competence to do so: they are competing with courts for expertise-based authority in this area.

\section{B. The Withering of Interest in Contract Interpretation}

Both Thayer and Holmes discussed contract interpretation and statutory interpretation as essentially equivalent practices, as seems to have been common at the time. ${ }^{134}$ But over the century since they wrote-particularly since the 1980s-this presupposition has become less common. Broad-spectrum scholarly interest in the interpretation of contracts (as opposed to other framings of the treatment of contracts, e.g., their design and the design of rules for their enforcement) has declined. This trend is probably regrettable.

Only six of the articles in the group assembled for this study address primarily contract interpretation (in contrast, 45 address constitutional interpretation, and 69 address statutory interpretation). Only three of these six were published after 1990, and the title of only one of those three makes it evident that the article does address contract interpretation. ${ }^{135}$ It is not apparent from this that contracts scholars are writing less about interpretation. The study shows only that scholarly work on contract interpretation receives fewer citations, and apparently less attention, across the scholarly spectrum than work on other types of legal interpretation does. This could be because scholars interested in public law do not tend to consult contracts scholarship, and not because contracts scholars do not find contract interpretation worth investigating. ${ }^{136}$ However, the content of the pieces on contract interpretation that did qualify for inclusion in the study does suggest that contracts scholars' interest has shifted away from issues

134 The same presupposition appears half a century later in Charles P. Curtis, A Better Theory of Legal Interpretation, 3 VAND. L. REV. 407 (1950), which is in the group of articles assembled for this study.

${ }^{135}$ Compare David Charny, Hypothetical Bargains: The Normative Structure of Contract Interpretation, 89 MicH. L. REV. 1815 (1991), with Ian Ayres \& Robert Gertner, Filling Gaps in Incomplete Contracts: An Economic Theory of Default Rules, 99 Yale L.J. 87 (1990); Alan Schwartz \& Robert E. Scott, Contract Theory and the Limits of Contract Law, 113 YALE L.J. 541 (2003).

${ }^{136}$ Cf., e.g., Steven J. Burton, Elements of Contract Interpretation 1 (2009) ("Issues of contract interpretation .... probably are the most frequently litigated issues on the civil side of the judicial docket.”). 
of verbal meaning and toward issues of institutional design and information management, often conceived as involving forms of expertise more akin to technical skill than to interpretive or linguistic competence. $^{137}$

The ebbing of interest in issues of contract interpretation among scholars interested in legal interpretation more generally seems unfortunate. The issues addressed by contracts theorists do have important parallels in other areas of law. ${ }^{138}$ We might understand the redirection of contract scholars' attention from issues of verbal meaning to issues of institutional design and information management as reflecting a practical recognition that academics are unlikely to settle abstract issues of meaning, especially the nature of meaning, while they might be able to reach some consensus on acceptable instruments for the management of meaning. If this is true, public law scholars' refusal to follow suit may reinforce the likelihood that they will continue to debate fundamental issues without reaching agreement.

\section{The Chevron Phenomenon}

Thayer and Holmes of course did not anticipate every feature of later legal interpretation scholarship. When they wrote, for example, administrative agencies were far less numerous and powerful than they are today, so it is not surprising that neither of them addressed how agency officials might interpret legal texts, or how such interpretations should be treated by courts (although they have both been cited in work addressing these issues). The earliest article on that topic in the group assembled for this study is Henry Monaghan's 1983 article Marbury and the Administrative State. ${ }^{139}$ Monaghan's approach to the issue, framed as a rebuttal of Thayer, anticipated the approach used by the Supreme Court in its Chevron decision the next year ${ }^{140}$ as well as in later academic work on the topic. Since the mid-1980s, the amount of academic work

\footnotetext{
${ }^{137}$ One of the main points of David Charny's 1991 article on "the normative structure of contract interpretation” is that issues of institutional design and information management have more to do with the interpretation of contracts than scholars are prone to think. Charny, supra note 135.

138 See, e.g., Einer Elhauge, Statutory DeFault Rules: How TO InTERPRET UnCLEAR LEGISLATION (2008); Randy E. Barnett, An Originalism for Nonoriginalists, 45 LOY. L. REV. 611 (1999); Jonathan R. Macey, Promoting Public-Regarding Legislation through Statutory Interpretation: An Interest Group Model, 86 CoLUM. L. REV. 223 (1986).

${ }^{139}$ Henry P. Monaghan, Marbury and the Administrative State, 83 COLUM. L. REV. 1 (1983).

${ }^{140}$ Chevron U.S.A. v. NRDC, 467 U.S. 837 (1984). The Chevron opinion did not cite Monaghan's article.
} 
on this topic has dramatically increased, ${ }^{141}$ and Chevron-focused pieces seem to accrue citations more rapidly than articles on other legal interpretation topics. ${ }^{142}$ But Monaghan's article was not simply a well-timed anticipation of issues that would shortly become significant as a result of real-world legal developments. The flood of scholarship on the topic seems due to other institutional developments as well, including developments specific to the academy.

As noted, Monaghan presented his investigation of the nature and scope of judicial power to review administrative agency decisions as, in part, a response to Thayer's deference thesis. ${ }^{143}$ Monaghan rejected Thayer's "effort to divorce meaning from validity"144 and argued that the decision in Marbury v. Madison ${ }^{145}$ demonstrated the inaccuracy of Thayer's distinction between legal interpretation and judicial review. In Marbury and since, Monaghan contended, the judicial role in passing on the constitutionality of legislation has indeed been understood as a matter of interpretation, and in this, it is just like judicial review of administrative action. ${ }^{146}$ Monaghan agreed with Thayer, however, that judges do not have a monopoly on interpretive authority, but "share[]" "responsibility for meaning" with agencies: "the judicial role is to specify what the statute cannot mean, and some of what it must mean, but not all that it does mean.”147

The next year, the Supreme Court approved the Environmental Protection Agency's interpretation of the Clean Air Act to permit the expansion of existing industrial installations without pollution-reducing upgrades. ${ }^{148}$ Chevron is best known not for its facts but for its articulation of a standard for judicial review of agency action. The standard involved a Monaghan-style conception of the expertise involved in judicial and agency activities as, above all, text-focused and interpretive: Chevron instructed courts, in reviewing agency action, first to interpret the legislation at issue to determine whether Congress had "spoken directly to the

\footnotetext{
${ }^{141}$ Of the 109 articles in Appendix A published since 1983, 55 concern statutory interpretation, and 17 concern agency interpretation in particular.

${ }^{142}$ The article with the third-highest weighted citation count among articles on statutory interpretation in the study concerns Chevron, as does the most recent article on the list. See Thomas W. Merrill \& Kristin E. Hickman, Chevron's Domain, 89 GEO. L.J. 833 (2001) (third-highest weighted citation count among articles addressing statutory interpretation); Cass R. Sunstein, Chevron Step Zero, 92 VA. L. REV. 187 (2006) (most recent).

${ }^{143}$ See Monaghan, supra note 139, at 7-11.

${ }^{144}$ Id. at 14; see also id. at 8, 13 n.75.

1455 U.S. (1 Cranch) 137 (1803).

${ }^{146}$ Monaghan, supra note 139, at 6 ("[J]udicial review in both constitutional and administrative law involves textual interpretation by the courts.”) (emphasis in original).

${ }^{147} I d$. at 27.

${ }^{148}$ Chevron U.S.A. v. NRDC, 467 U.S. 837 (1984).
} 
precise question" and, if it had not, to defer to the agency's "permissible construction" of the statute. $^{149}$

Despite Chevron's now-canonical status, commentators did not immediately herald it as dominating the doctrine in this area. The first article on the subject following Monaghan's in the group assembled for this study postdated Chevron but cited the case only once. ${ }^{150}$ Not until 1989 did commentators begin describing Chevron, initially with reservations, as a sea change. ${ }^{151}$ The belated recognition of Chevron as a watershed by commentators was not just a reaction ${ }^{152}$ to the decision but also an effect of an explosion of scholarship concerning the case's significance and implementation. The flowering of scholarship on this topic coincided with a more general flowering of high-profile work on legal interpretation, especially statutory interpretation, in the 1980s. ${ }^{153}$ The group of works assembled for this study is dominated by more recent articles, and especially by articles published between 1983 and 1992. ${ }^{154}$ The period was marked not just by increased output but also by increased use of other disciplinary resources. These trends were themselves the focus of several articles in the group assembled for this study. ${ }^{155}$

This context of the flowering of Chevron scholarship itself occurred within an even broader context: the contemporary exacerbation of a perceived divide between the academy and the culture at large that destabilized traditional conceptions of the purposes of academic work

${ }^{149}$ Id. at 842-43.

${ }^{150}$ Colin S. Diver, Statutory Interpretation in the Administrative State, 133 U. Pa. L. Rev. 549,596 n.250 (1985).

${ }^{151}$ Cynthia R. Farina, Statutory Interpretation and the Balance of Power in the Administrative State, 89 CoLUM. L. REV. 452, 456 (1989); Antonin Scalia, Judicial Deference to Administrative Interpretations of Law, 1989 DUKE L.J. 511, 512 (1989); Cass R. Sunstein, Interpreting Statutes in the Regulatory State, 103 HARV. L. REV. 405,445 (1989).

152 See Rubin, supra note 36, at 1883-85 (arguing that all legal scholarship is necessarily "reactive”).

153 See Rubin, supra note 13, at 932-33; Jean Stefancic, The Law Review Symposium Issue: Community of Meaning or Re-Inscription of Hierarchy?, 63 U. COLO. L. REV. 651, 657 (1992).

154 The earliest year covered in Appendix A represented by more than four articles is 1982. Four articles on the list (three of them on constitutional interpretation) were published in 1975; four were published in 1981 (again including three on constitutional interpretation). For the 1982 to 1991 period, the list includes 7 articles from 1983; 3 from 1984; 7 from 1985; 5 from 1986; 9 from 1987; 7 from 1988; 9 from 1989; 12 from 1990; 6 from 1991; and from 1992. During this period, only one year produced fewer than five articles that eventually received more than 100 citations.

155 See, e.g., Richard A. Posner, Law and Literature: A Relation Reargued, 72 VA. L. REV. 1351 (1986); J.M. Balkin, Deconstructive Practice and Legal Theory, 96 YALE L.J. 743 (1987); Michael S. Moore, The Interpretive Turn in Modern Theory: A Turn for the Worse, 41 STAN. L. REV. 871 (1989); Peter C. Schanck, Understanding Postmodern Thought and Its Implications for Statutory Interpretation, 65 S. CAL. L. REV. 2505 (1992). 
and put added pressure on academics to legitimate that work. ${ }^{156}$ Andrew Abbott's work has suggested, and shown, that when an academic community experiences this kind of pressure, those at the core of the community will emphasize their control over abstract resources that they can define themselves - they withdraw into "pure work" ${ }^{157}$ —and will seek new conceptual territory to occupy by bridging existing subject areas and by drawing new "fractal” distinctions between their own and previous work. ${ }^{158}$ The work on Chevron from the late 1980s on typifies such responses. After Monaghan and then the Court identified an abstract, theorizable, and textual core to the problem of judicial review of agency action, legal scholars eventually recognized an opportunity to claim expertise in this "pure" domain and to justify their claim by reference to multiple bodies of prior scholarship. And as is illustrated by the most recent article in the study, Cass Sunstein’s Chevron Step Zero, ${ }^{159}$ “fractalization” has continued to occur even within this new subfield: over time, the most visible articles on the topic have increasingly focused on analyzing components of the Chevron “two-step” rather than the doctrine's place within the legal system.

The appearance of this subfield, then, may be as much a product of forces mostly internal to the academy as of forces clearly outside it, like the Chevron decision itself. This aspect of their activity has remained largely unseen by the academics involved, who remain preoccupied with the issues that divided Thayer and Holmes: the tension between subjective and objective conceptions of verbal and legal meaning, and more fundamentally, the appropriate scope of interpretive authority and the location of interpretive expertise.

\section{Citation PATterns AND PRACTiCES}

More general features of the group of articles covered in this study include the citation links between the articles on the list, and the network created by these links, addressed in this Part. ${ }^{160}$ The characteristics of this network confirm that academics themselves continue to treat

156 See supra notes 25-27 and accompanying text.

157 See AввотT, supra note 63, at 22.

${ }^{158}$ Id. at $130,230-31$.

159 Sunstein, supra note 142.

${ }^{160}$ Most studies of citation networks begin by collecting all articles published on a particular topic during a particular period. For the present study, this would be all articles published on general topics in legal interpretation between 1893 and 2010. The absence of machine indexing of the kind needed made this approach impossible for 
scholarship on legal interpretation as a coherent research area. It also reinforces the conclusions suggested in the previous Part: even though, at certain points, this scholarship has been read mostly by other scholars, many of those working in the area seem to lack an accurate sense of the overall shape of their field and the implications this context has for their asserted aims.

\section{A. Cross-Citation and Embeddedness}

To analyze the citation relationships among the articles, I identified all citations to prior articles by subsequent articles in the group and divided the 154 articles into four categories, based on the type of legal instrument addressed by each article. The two largest categories contain articles addressing constitutional interpretation (44 articles) and statutory interpretation (67 articles). A small group contains articles addressing contract interpretation (6 articles). About a fifth of the articles explicitly consider multiple types of legal text or the nature of verbal meaning in general as it relates to legal practices (37 articles).

The citation links among the articles in the whole list and in different subcategories create a "directed" network, one in which the connections between members of the population are oneway. ${ }^{161}$ Directed networks differ from nondirected ones. In a nondirected network, connections between members are symmetrical. A telephone network is an example: if I can call you on the phone, you can call me. In a directed network, like a citation network, the existence of a link between two members does not enable both linked members equally: if my article cites your article, it does not necessarily follow that your article cites my article. In a directed network, one can not only identify the most-linked articles, but also, among other things, compare articles’ outgoing connections (their citations of other articles), or "outdegree," and their incoming connections (citations of them by others), or "indegree.”162

As Appendix B shows, the articles as a group form a single connected network (with a few entirely isolated members). Although articles in each subcategory tend to be most connected to others in the same subcategory, no subcategory is entirely isolated. This feature of the

this study. A smaller study may still be valuable, since citation networks are scale-free in most regards. See supra notes 68. In assessing characteristics of this network, I adjusted my conclusions to take the limited size of the population into account.

${ }^{161}$ See, e.g., Newman, supra note 70 , at 173, 176-78.

${ }^{162}$ See, e.g., id. 
network might suggest that legal academics generally assume, with Holmes and Monaghan, that different actors' determinations of the meanings of different kinds of legal texts are comparable activities. But the network's interconnectedness is probably also a record of the kind of "jurisdictional" competition theorized by Abbott ${ }^{163}$ and evidence that the dynamics of legal scholarship in this area differ from that in some others. ${ }^{164}$ Institutional pressures impel scholars to divide their topics into increasingly smaller and more abstract bits, but at the same time to tie their work to existing literature as broadly as possible.

These observations are supported by consideration of the articles' in- and outdegree characteristics. ${ }^{165}$ Although the article with the highest indegree (cited by other articles in the list the greatest number of times) was in the constitutional law category, ${ }^{166} 16$ of the 20 articles with the highest indegree ${ }^{167}$ were in the statutory interpretation category, ${ }^{168}$ and more than half of the 20 articles with the highest outdegree were in the same category. ${ }^{169}$ This dominance is partly due to the size of the statutory interpretation subcategory, its prevalence since the $1980 \mathrm{~s},{ }^{170}$ and the fact that over the past several decades, the average number of citations per article has been growing. But the indegree of the most highly cited articles is disproportionate to their numerical dominance. Over time, articles within the theoretical core of this research area seem to be citing each other more frequently, across subcategory lines. The often-noted increasing length and number of citations of law review articles might reflect not just a kind of arms race ${ }^{171}$ but also

163 See supra notes 157159 and accompanying text.

${ }^{164}$ See supra notes 102107 and accompanying text.

165 To approximate the articles' in- and outdegrees, the number of links to other articles in the group was divided by the number of possible links to other articles in the group. This denominator was different for each article depending on its place in the sequence of articles. This method was used even though, occasionally, articles in the group cited articles with publication dates following those of the citing articles.

${ }^{166}$ Stephen R. Munzer \& James W. Nickel, Does the Constitution Mean What It Always Meant?, 77 CoLUM. L. REV. 1029 (1977).

${ }^{167}$ Of the 13 articles with an indegree of zero (i.e., cited by no other articles in the list), eight were published since 2000, six in the statutory interpretation category.

168 Of the other 4 articles with high indegree, 2 were in the constitutional category and 2 in the "multiple" category. Many of these articles were written by authors who self-cite extensively. Self-citation may be a complicating factor in analyzing citation networks but is often ignored. It is impossible to tell whether a particular self-citation is strategic or genuine; there is no reason to penalize productive generators of network members just for being productive; and a generator of network members will rarely be so productive as to single-handedly control the shape of the network.

16912 of the 20 articles with the highest outdegree were in the legislation category, 5 in the constitutional category, and 3 in the "multiple" category.

170 See supra note 153 and accompanying text.

${ }^{171}$ See Austin, supra note 40, at 1143. 
the increasing complexity of the terrain within which some legal academics are trying to stake out their conceptual territory. In the absence of an institutional consensus on the shape and aims of legal scholarship, as each writer seeks to ground a new work's claim to relevance and legitimacy, the writer has to invoke a constantly increasing number of reference points.

A similar story seems to be told by another feature of the network: the relationship between articles' rate of citation by other articles in the study and their rate of citation overall. Articles with a higher measure on this feature would seem to be relatively more visible to other scholars working on general legal interpretation topics (more deeply embedded in the core theoretical part of the field), and relatively less visible (or useful) to scholars working on specific topics in legal interpretation (e.g., advocating a particular understanding of a particular text) or in other areas. The articles with the highest measure on this feature were disproportionately produced during the 1982 to 1991 period discussed above ${ }^{172}$ and overlap only minimally with the articles on the list that have earned the greatest number of judicial citations. ${ }^{173}$ In other words, much of the most visible scholarship produced during that fruitful period has earned its citations disproportionately from other jurisdiction-defining work on general topics in interpretation, rather than from the scholarly community at large or from judicial citation. The claim to authority to define interpretive expertise in these theoretical works has become self-fulfilling, primarily within a closed community of academics.

\section{B. Macro-Patterns and Micro-Rhetoric}

This, of course, is the fear of many legal academics and the charge made by many of their critics. ${ }^{174}$ Understanding how legal scholarship fits into the wider disciplinary field could go far toward addressing these fears and criticisms by helping to clarify the actual shape of that scholarship as a literature. As noted in Part II, this is exactly what some bibliometric work tries to do. The work done on legal scholarship so far has proposed that in certain areas, this

\footnotetext{
${ }^{172}$ Of the 21 articles with the highest measure on this feature, 16 were published between 1982 and 1991. (The same period was responsible for a lower proportion of articles overall, 85 of 150.)

173 The only articles on both lists were Holmes, supra note 117; Richard A. Posner, Statutory Interpretation-In the Classroom and in the Courtroom, 50 U. CHI. L. REV. 800 (1983); and Richard Pildes, Note, Intent, Clear Statements, and the Common Law: Statutory Interpretation in the Supreme Court, 95 HARV. L. REV. 892 (1982).

${ }^{174}$ See, e.g., supra note 43.
} 
scholarship most resembles "cumulating” scientific scholarship. ${ }^{175}$ The group of articles considered in this study does not fit this pattern. But there is a tension between the macro-shape of the citation network created by these articles and much of the micro-rhetoric they contain.

In the natural sciences, citation patterns have mostly been found to follow a "research front” model consistent with Kuhn's conception of progress during periods of normal science. Plotted on a grid, which registers cited articles in rows and citing articles in columns, with a mark at the intersections of citing columns and cited rows, this type of pattern clusters citations along the diagonal representing the research front. ${ }^{176}$ Random citation practices scatter citation marks more evenly throughout the triangular portion of the grid; overcitation of foundational sources clusters citations along the top rows of the grid. These two patterns are characteristic of the humanities and social sciences. ${ }^{177}$ As Appendix C shows, overall, the articles considered in this study cite other articles in the study in a random-citation pattern, with citations distributed throughout the grid. But during some periods — especially 1982 to 1987 and 1991 to 2000 — the body of the grid empties out a bit, and citations cluster more along the diagonal. The overall pattern displayed by this particular group of articles, then, confirms Becher's characterization of law as a soft discipline lacking convergence. ${ }^{178}$ It would make sense for this characterization to be especially accurate with respect to subfields of academic law that deal with such abstract and contested concepts as textual meaning.

This conclusion is not surprising, since the field in question has traditionally borrowed often and heavily from the humanities. All the same, most legal scholars, including those writing in the areas studied here, adopt a rhetoric more characteristic of the sciences: the " 'anti-rhetoric' of legal discourse closely parallels the conventional view of modern scientific discourse,” overusing abstract grammatical agents and describing power relations mostly in mechanistic terms. ${ }^{179}$ The presence of such rhetoric is probably overdetermined in this specific area. Not just a form of false consciousness, it is a product of the plural normative and discursive systems to which legal academics owe allegiance and within which they seek to justify their activities. Such

${ }^{175}$ See supra notes 104105 and accompanying text.

${ }^{176}$ Hargens, supra note 82, at 848.

${ }^{177} I d$.

${ }^{178}$ See supra notes 58-62 and accompanying text.

${ }^{179}$ Coulson, supra note 106, at 194 (quoting and discussing Peter Brooks, Narrative Transactions-Does the Law Need a Narratology?, 18 YALE J.L. \& HuMAN. 1, 20 (2006)). 
rhetoric lends scholarly descriptions and prescriptions a "hardness" that can establish and clarify legal scholars’ expertise vis-à-vis legal decision makers. But it is an unstable rhetoric, especially in work that by its very nature seeks to both capitalize on and deny the role played by interpretation in other academic and professional discourses.

The result is an "invisible college" that is also a "Tower of Babel."180 The constant churning at the center of this field, which is continually reorienting itself with respect to its own foundational texts and other disciplinary vocabularies, exacerbates this dynamic. As legal academics seek to establish their expertise with respect to particular interpretive issues, they fracture the field, increasing the opportunities for claiming expertise, but also pin their claims to heterogeneous vocabularies, probably making those claims more tenuous.

\section{CONCLUSION}

Legal academics’ willingness to consider the institutional determinants of their scholarly output has been oddly limited. In particular, they have resisted examining what the texts they produce have to tell them about the value and nature of their collective efforts. This resistance is especially confounding in the area of scholarship on topics in legal interpretation, in which scholarly awareness of the systemic significance of the written word has always been acute. American legal academics' output in this area supports intuitions about the peculiar status of legal scholarship among the academic disciplines and in relation to professional legal discourse, but also suggests that this status carries special dangers, even as it makes work in this area especially attractive. This article does not hope to offer the last word on the topic, but seeks only to persuade readers that systematic analysis of the kind sketched here might help legal academics reach more agreement about what their work does and should achieve.

${ }^{180}$ Cf. Eleanor Marie Brown, The Tower of Babel: Bridging the Divide Between Critical Race Theory and “Mainstream” Civil Rights Scholarship, 103 YALE L.J. 513, 515-16 (1995). 
APPENDIX A

MOST-CITED AMERICAN LAW REVIEW ARTICLES ON LEGAL INTERPRETATION

This appendix lists the 154 most-cited articles published in American law reviews on general issues in legal interpretation. It includes studies of interpretive practice and authority, as well as analyses of the role of interpretation in legal reasoning and defenses or critiques of particular interpretive methods. It also includes articles focusing on specific categories of legal texts (such as contracts, constitutions, and statutes), specific interpreters, and specific interpretive principles. But it does not include articles focusing on the meaning of specific legal texts or on specific doctrinal areas, such as the interpretation of environmental statutes.

The list was compiled from a list of the articles published in American law reviews, indexed in Hein Online, containing the word "interpretation," and cited more than 100 times (by Hein Online's count). Hein Online was used because of the greater historical coverage of its law review database.

Articles are listed in the order of citation frequency, that is, total number of citations in Hein Online. This list also includes weighted citation information, corresponding to the approximate number of citations of the article per year since its publication, based on the approximate number of possible citations in an American law review as of the article's year of publication. Some articles are marked with asterisks. The number of citations listed for these articles is likely underreported because the articles in question, or significant portions of them, were later republished in frequently cited books.

\section{Article}

1. Robert M. Cover, Foreword: Nomos and Narrative, 97 HARv. L. REV. 4 (1983).

2. * H.L.A. Hart, Positivism and the Separation of Law and Morals, 71 HARV. L. REV. 593 (1958).

3. * Antonin Scalia, The Rule of Law as a Law of Rules, 56 U. CHI. 833 L. REV. 1175 (1989).

4. Karl N. Llewellyn, Remarks on the Theory of Appellate Decision 803 and the Rules or Canons about How Statutes Are to Be Construed, 3 VAND. L. REV. 395 (1950).

5. Felix Frankfurter, Some Reflections on the Reading of Statutes, 779 47 Colum. L. REV. 527 (1947).

\section{No. cites Weighted}

$1170 \quad 1.510$

$912 \quad .745$

1.333

.608

.577 


\section{Article}

6. Thomas C. Grey, Do We Have an Unwritten Constitution?, 27 STAN. L. REV. 703 (1975).

7. James Bradley Thayer, The Origin and Scope of the American Doctrine of Constitutional Law, 7 HARV. L. REV. 129 (1893).

8. William N. Eskridge, Jr., The New Textualism, 37 UCLA L. REV. 730 621 (1990).

9. Lon L. Fuller, Positivism and Fidelity to Law-A Reply to Professor Hart, 71 HARV. L. REV. 630 (1958).

10. Ian Ayres \& Robert Gertner, Filling Gaps in Incomplete Contracts: An Economic Theory of Default Rules, 99 YALE L.J. 87 (1990).

11. H. Jefferson Powell, The Original Understanding of Original Intent, 98 HARV. L. REV. 885 (1985).

12. * Mark V. Tushnet, Following the Rules Laid Down: A Critique of Interpretivism and Neutral Principles, 96 HARV. L. REV. 781 (1983).

13. Henry P. Monaghan, The Constitutional Common Law, 89 HARV. L. REV. 1 (1975).

14. Richard Delgado, Storytelling for Opportunists and Others: A Plea for Narrative, 87 MicH. L. REV. 2411 (1989).

15. Owen M. Fiss, Objectivity and Interpretation, 34 STAN. L. REV. 739 (1982).

16. Jonathan R. Macey, Promoting Public-Regarding Legislation through Statutory Interpretation: An Interest Group Model, 86 COLUM. L. REV. 223 (1986).

17. Max Radin, Statutory Interpretation, 43 HARV. L. REV. 863 (1930).

18. Cass R. Sunstein, Interpreting Statutes in the Regulatory State, 103 HARV. L. REV. 405 (1989).

19. Frank Easterbrook, Statutes’ Domains, 50 U. CHI. L. REV. 533 (1983).

20. * William N. Eskridge, Jr., Dynamic Statutory Interpretation, 525 135 U. PA. L. REV. 1479 (1987).

21. Robert M. Cover, Violence and the Word, 95 YALE L.J. 1601 (1986).

22. William N. Eskridge, Jr. \& Philip P. Frickey, Statutory Interpretation as Practical Reasoning, 42 STAN. L. REV. 321 (1990).

23. Paul Brest, The Misconceived Quest for the Original Understanding, 60 B.U. L. REV. 204 (1980).

24. Antonin Scalia, Judicial Deference to Administrative Interpretations of Law, 1989 DUKE L.J. 511 (1989).

$\begin{array}{ll}\text { No. cites } & \begin{array}{l}\text { Weighted } \\ 757\end{array} \\ 746\end{array}$

1.217

.585

1.165

.941

.875

.696

1.037

.753

.847

.186

.909

.688

.840

.736

512

.853

504

.593

470

.752 


\section{Article}

25. Henry P. Monaghan, Our Perfect Constitution, 56 N.Y.U. L. REV. 353 (1981).

26. Cass R. Sunstein, Law and Administration After Chevron, 90 ColuM. L. REV. 2071 (1990).

27. Stephen Breyer, On the Uses of Legislative History in Interpreting Statutes, 65 S. CAL. L. REV. 845 (1992).

28. Roscoe Pound, Common Law and Legislation, 21 HARV. L. REV. 380 383 (1908).

29. Cynthia R. Farina, Statutory Interpretation and the Balance of Power in the Administrative State, 89 COLUM. L. REV. 452 (1989).

30. Richard A. Posner, Statutory Interpretation-In the Classroom and in the Courtroom, 50 U. CHI. L. REV. 800 (1983).

31. William N. Eskridge, Jr., Overriding Supreme Court Statutory Interpretation Decisions, 101 YALE L.J. 331 (1991).

32. Henry Paul Monaghan, Stare Decisis and Constitutional Adjudication, 88 Colum. L. REV. 723 (1988).

33. Patricia M. Wald, Some Observations on the Use of Legislative History in the 1981 Supreme Court Term, 68 IOWA L. REV. 195 (1983).

34. Kathryn Abrams, Hearing the Call of Stories, 79 CAL. L. REV. 971 (1991).

35. Richard H. Fallon, Jr., A Constructivist Coherence Theory of Constitutional Interpretation, 100 HARV. L. REV. 1189 (1987).

36. * Sanford Levinson, Law as Literature, 60 TEX. L. REV. 373 (1982).

37. T. Alexander Aleinikoff, Updating Statutory Interpretation, 87 MiCH. L. REV. 20 (1988).

38. William N. Eskridge, Jr. \& Philip P. Frickey, QuasiConstitutional Law: Clear Statement Rules As Constitutional Lawmaking, 45 VAND. L. REV. 593 (1992).

39. Thomas W. Merrill, Judicial Deference to Executive Precedent, 101 YALE L.J. 969 (1992)

40. Oliver Wendell Holmes, The Theory of Legal Interpretation, 12 HARV. L. REV. 417 (1899).

41. David A. Strauss, Common Law Constitutional Interpretation, 303 63 U. CHI. L. REV. 877 (1996).

42. Henry P. Monaghan, Marbury and the Administrative State, 83295 COLUM. L. REV. 1 (1983).

43. Michael Stokes Paulsen, The Most Dangerous Branch: Executive Power to Say What the Law Is, 83 GEO. L.J. 217 (1994).

44. * Ronald Dworkin, The Forum of Principle, 56 N.Y.U. L. REV. 293 469 (1981).

$\begin{array}{ll}\begin{array}{ll}\text { No. cites } \\ 436\end{array} & \begin{array}{l}\text { Weighted } \\ .528\end{array} \\ 407 & .678 \\ 393 & .728 \\ 380 & .254 \\ 371 & .594 \\ 369 & .476 \\ 364 & .639 \\ 345 & .531 \\ 342 & .441\end{array}$

342

.6

334

.495

331

.414

319

.491

316

.585

.578

.202

.721

.381

.612

.355 
Article

45. William N. Eskridge, Jr., Politics without Romance: Implications of Public Choice Theory for Statutory Interpretation, 74 VA. L. REV. 275 (1988).

46. Laurence H. Tribe, Taking Text and Structure Seriously:

Reflections on Free-Form Method in Constitutional Interpretation, 108 HARV. L. REV. 1221 (1995).

47. William N. Eskridge, Jr., Public Values In Statutory Interpretation, 137 U. PA. L. REV. 1007 (1989).

48. James M. Landis, A Note on "Statutory Interpretation,” 43 HARV. L. REV. 886 (1930).

49. Paul Brest, The Conscientious Legislator's Guide to Constitutional Interpretation, 27 STAN. L. REV. 585 (1975).

50. J.M. Balkin, Deconstructive Practice and Legal Theory, 96 YALE L.J. 743 (1987).

51. Akhil Reed Amar, Intratextualism, 112 HARV. L. REV. 747 (1999).

52. William N. Eskridge \& Philip P. Frickey, Law as Equilibrium, 253 108 HARV. L. REV. 26 (1994).

53. Lawrence Lessig, Fidelity in Translation, 71 TEX. L. REV. 1165246 (1993).

54. Thomas W. Merrill \& Kristin E. Hickman, Chevron’s Domain, 246 89 GEO. L.J. 833 (2001).

55. Thomas C. Grey, The Constitution as Scripture, 37 STAN. L. REV. 1 (1984).

56. Larry Alexander \& Frederick Schauer, On Extrajudicial Constitutional Interpretation, 110 HARV. L. REV. 1359 (1997).

57. Lon L. Fuller, The Case of the Speluncean Explorers, 62 HARV. L. REV. 616 (1949).

58. Richard A. Posner, Legal Formalism, Legal Realism, and the Interpretation of Statutes and the Constitution, 37 CASE W. RES. L. REV. 179 (1986).

59. Suzanna Sherry, The Founders' Unwritten Constitution, 54 U. 232 CHI. L. REV. 1127 (1987).

60. Daniel A. Farber \& Philip P. Frickey, Legislative Intent and 232 Public Choice, 74 VA. L. REV. 423 (1988).

61. Richard Pildes, Note, Intent, Clear Statements, and the Common Law: Statutory Interpretation in the Supreme Court, 95 HARV. L. REV. 892 (1982).

62. Akhil Reed Amar, The Document and the Doctrine, 114 HARV. 226 L. REV. 26 (2000).

63. Colin S. Diver, Statutory Interpretation In the Administrative State, 133 U. PA. L. REV. 549 (1985).
No. cites Weighted

.449

.644

.453

.391

.276

.384

.776

.527

.482

1.025

.324

.623

.177

.337 


\section{Article}

64. Richard A. Posner, Economics, Politics, and the Reading of Statutes and the Constitution, 49 U. CHI. L. REV. 263 (1982).

65. Edwin Meese III, The Law of the Constitution, 61 TUL. L. REV. 979 (1987).

66. Patricia M. Wald, The Sizzling Sleeper: The Use of Legislative History in Construing Statutes in the 1988-89 Term of the United States Supreme Court, 39 AM. U. L. REV. 277 (1990).

67. Terrance Sandalow, Constitutional Interpretation, 79 MiCH. L. 202 REV. 1033 (1981).

68. Lawrence Lessig, Understanding Changed Readings: Fidelity and Theory, 47 STAN. L. REV. 395 (1995).

69. Michael S. Moore, A Natural Law Theory of Interpretation, 58 S. CAL. L. REV. 277 (1985).

70. Richard S. Kay, Adherence to the Original Intentions in Constitutional Adjudication: Three Objections and Responses, 82 Nw. U. L. REV. 226 (1988).

71. Charles J. Goetz \& Robert E. Scott, The Limits of Expanded Choice: An Analysis of the Interactions between Express and Implied Contract Terms, 73 CAL. L. REV. 261 (1985).

72. Richard J. Pierce, Jr., The Supreme Court's New Hypertextualism: An Invitation to Cacophony and Incoherence in the Administrative State, 95 CoLUM. L. REV. 749 (1995).

73. John F. Manning, Textualism as a Nondelegation Doctrine, 97 COLUM. L. REV. 673 (1997).

74. Kenneth W. Starr, Observations about the Use of Legislative History, 1987 DuKE L.J. 371 (1987).

75. Martha Minow, Interpreting Rights: An Essay for Robert Cover, 96 YALE L.J. 1860 (1987).

76. * John Hart Ely, Constitutional Interpretivism: Its Allure and 183 Impossibility, 53 IND. L.J. 399 (1978).

77. H. Jefferson Powell, Rules for Originalists, 73 VA. L. REV. 659182 (1987).

78. Michael J. Perry, The Authority of Text, Tradition, and Reason: A Theory of Constitutional "Interpretation," 58 S. CAL. L. REV. 551 (1985).

79. Paul Brest, Interpretation and Interest, 34 STAN. L. REV. 765 (1982).

80. Nicholas S. Zeppos, Legislative History and the Interpretation of Statutes: Toward a Fact-Finding Model of Statutory Interpretation, 76 VA. L. REV. 1295 (1990).

81. John F. Manning, Textualism and the Equity of the Statute, 101 COLUM. L. REV. 1 (2001).

82. Stanley Fish, Fish v. Fiss, 36 StAn. L. REV. 1325 (1984).
180

No. cites

222 Weighted .278

.326

.362

.245

.442

.272

.302

.261

.418

.479

.274

.274

.206

.270

.250

.225

.295

.648

172 


\section{Article}

83. William N. Eskridge, Jr., Interpreting Legislative Inaction, 87 MiCH. L. REV. 67 (1988).

84. Michael S. Moore, The Semantics of Judging, 54 S. CAL. L. REV. 167 151 (1981).

85. David L. Shapiro, Continuity and Change in Statutory Interpretation, 67 N.Y.U. L. REV. 921 (1992).

86. Arthur W. Murphy, Old Maxims Never Die: The "PlainMeaning Rule" and Statutory Interpretation in the Modern Federal Courts, 75 ColuM. L. REV. 1299 (1975).

87. John F. Manning, Constitutional Structure and Judicial Deference to Agency Interpretations of Agency Rules, 96 COLUM. L. REV. 612 (1996).

88. Robert A. Anthony, Which Agency Interpretations Should Bind Citizens and the Courts, 7 YALE J. ON REG. 1 (1990)

89. * Ronald Dworkin, Law as Interpretation, 60 TEX. L. REV. 527161 (1982).

90. Richard J. Pierce, Jr., Chevron and Its Aftermath: Judicial Review of Agency Interpretations of Statutory Provisions, 41 VAND. L. REV. 301 (1988).

91. Alan Schwartz \& Robert E. Scott, Contract Theory and the Limits of Contract Law, 113 YALE L.J. 541 (2003).

92. Steven L. Winter, The Cognitive Dimension of the Agon between Legal Power and Narrative Meaning, 87 MiCH. L. REV. 2225 (1989).

93. Karl N. Llewellyn, The Constitution as an Institution, 34 COLUM. L. REV. 1 (1934).

94. Robert A. Anthony, Interpretive Rules, Policy Statements, Guidances, Manuals, and the Like-Should Federal Agencies Use Them to Bind the Public?, 41 DuKE L.J. 1311 (1992).

95. Robin B. Johansen, Note, The New Federalism: Toward a Principled Interpretation of the State Constitution, 29 STAN. L. REV. 297 (1977).

96. Clark D. Cunningham, The Lawyer as Translator, Representation as Text: Towards an Ethnography of Legal Discourse, 77 CORNELL L. REV. 1298 (1991).

97. Edwin W. Patterson, The Interpretation and Construction of Contracts, 64 COLUM. L. REV. 833 (1964).

98. David Charny, Hypothetical Bargains: The Normative Structure of Contract Interpretation, 89 MiCH. L. REV. 1815 (1991).

99. Jane S. Schacter, Metademocracy: The Changing Structure of Legitimacy in Statutory Interpretation, 108 HARV. L. REV. 593 (1995).

$\begin{array}{ll}\text { No. cites } & \begin{array}{l}\text { Weighted } \\ 169\end{array} \\ .260 \\ 167 & .202 \\ 165 & .306 \\ 163 & .171\end{array}$

163 .388

162 .270 .201

161 .248

161 .767

158 .253

155 .107

154 .285

149 .163 


\section{Article}

100. Roscoe Pound, The Theory of Judicial Decision, 36 HARV. L. REV. 641 (1923).

101. William N. Eskridge, Jr., Gadamer/Statutory Interpretation, 90 ColuM. L. REV. 609 (1990).

102. Robert Weisberg, The Calabresian Judicial Artist: Statutes and the New Legal Process, 35 Stan. L. ReV. 213 (1983).

103. Gerald C. MacCallum Jr., Legislative Intent, 75 YALE L.J. 754135 (1966).

104. Thomas S. Schrock \& Robert C. Welsh, Reconsidering the Constitutional Common Law, 91 HARV. L. REV. 1117 (1978).

105. Ralph G. Steinhardt, The Role of International Law As a Cano of Domestic Statutory Construction, 43 VAND. L. REV. 1103 (1990).

106. William N. Eskridge, Jr., Textualism, The Unknown Ideal?, 96 MiCH. L. REV. 1509 (1998) (book review).

107.* Robert H. Bork, The Constitution, Original Intent, and Economic Rights, 23 SAN DIEGo L. REV. 823 (1986).

108. Lawrence C. Marshall, “Let Congress Do It": The Case for an Absolute Rule of Statutory Stare Decisis, 88 MicH. L. REV. 177 (1989).

109. Roscoe Pound, The Theory of Judicial Decision, 36 HARV. L. REV. 940 (1923).

110. Paul W. Kahn, Interpretation and Authority in State Constitutionalism, 106 HARV. L. REV. 1147 (1993).

111. Frederick Schauer, An Essay on Constitutional Language, 29 UCLA L. REV. 797 (1982).

112. Daniel A. Farber, The Inevitability of Practical Reason:

No. cites Weighted

$139 \quad .013$

138

.230

.175

.122

134

.151

.223

.367

131

.187

130

.208

.090

129

.253

.160

113. E. Allan Farnsworth, “Meaning” in the Law of Contracts, 76

114. Randy E. Barnett, An Originalism for Nonoriginalists, 45 LOY. 126

115. Edward L. Rubin, Beyond Public Choice: Comprehensive

116. Stephen R. Munzer \& James W. Nickel, Does the Constitution

117. Robert F. Nagel, The Formulaic Constitution, 84 MiCH. L. REV.

118. Cass R. Sunstein, Chevron Step Zero, 92 VA. L. REV. 187
Statutes, Formalism, and the Rule of Law, 45 VAND. L. REV. 533 (1992).

.115 YALE L.J. 939 (1967).

.382 L. REV. 611 (1999).

124

.218 Rationality in the Writing and Reading of Statutes, 66 N.Y.U. L. REV. 1 (1991).

123

.135 Mean What It Always Meant?, 77 CoLUM. L. REV. 1029 (1977). 165 (1985).

123

.235 (2006) 


\section{Article}

119. David L. Faigman, Normative Constitutional Fact-Finding: Exploring the Empirical Component of Constitutional Interpretation, 139 U. PA. L. REV. 541 (1991).

120. Michael J. Gerhardt, The Role of Precedent in Constitutional Decisionmaking and Theory, 60 GEO. WASH. L. REV. 68 (1991).

121. Note, Looking It Up: Dictionaries and Statutory Interpretation, 107 HARV. L. REV. 1437 (1994).

122. Nicholas S. Zeppos, Justice Scalia’s Textualism: The "New” New Legal Process, 12 CARdOzo L. REV. 1597 (1991).

123. Curtis A. Bradley, The Charming Betsy Canon and Separation of Powers: Rethinking the Interpretive Role of International Law, 86 GEO. L.J. 479 (1998).

124. Daniel A. Farber, The Originalism Debate: A Guide for the Perplexed, 49 OHIO ST. L.J. 1085 (1989).

125. * Stanley Fish, Working on the Chain Gang: Interpretation in 116 Law and Literature, 60 TEX. L. REV. 551 (1982).

126. Michael S. Moore, The Interpretive Turn in Modern Theory: A Turn for the Worse, 41 STAN. L. REV. 871 (1989).

127. Laurence H. Silberman, Chevron-The Intersection of Law \& Policy, 58 GEO. WASH. L. REV. 821 (1990).

128. Mark Seidenfeld, A Syncopated Chevron: Emphasizing Reasoned Decisionmaking in Reviewing Agency Interpretations of Statutes, 73 TEX. L. REV. 83 (1994).

129. Charles R. Lawrence III, The Word and the River: Pedagogy as Scholarship as Struggle, 65 S. CAL. L. REV. 2231 (1992).

130. Frederick Schauer, Statutory Construction and the Coordinating Function of Plain Meaning, 1990 SUP. CT. REV. 231 (1990).

131. Philip P. Frickey, From the Big Sleep to the Big Heat: The Revival of Theory in Statutory Interpretation, 77 MINN. L. REV. 241 (1992).

132. Richard H. Fallon, Jr., Implementing the Constitution, 111 HARV. L. REV. 54 (1997).

133. Charles P. Curtis, A Better Theory of Legal Interpretation, 3 VAND. L. REV. 407 (1950).

134. William Popkin, An “Internal” Critique of Justice Scalia's Theory of Statutory Interpretation, 76 MinN. L. REV. 1133 (1992).

135. Jerome Frank, Words and Music: Some Remarks on Statutory 109 Interpretation, 47 CoLUM. L. REV. 1259 (1947).

136. Stephen Breyer, Our Democratic Constitution, 77 N.Y.U. L. 107 REV. 245 (2002).

137. Owen M. Fiss, Conventionalism, 58 S. CAL. L. REV. 177 (1985). 105
.080

\section{No. cites Weighted}

$122 \quad .214$

121

.212

.252

.209

.331

.189

.145

.184

.192

.240

.213

.188

.207

.287

.084

.204

.446

.145 


\section{Article}

138. Richard A. Posner, Law and Literature: A Relation Reargued, 72 VA. L. REV. 1351 (1986).

139. W. David Slawson, Legislative History and the Need to Bring Statutory Interpretation under the Rule of Law, 44 STAN. L. REV. 383 (1992).

140. Nicholas Quinn Rosenkranz, Federal Rules of Statutory Interpretation, 115 HARV. L. REV. 2085 (2002).

141. John G. Wofford, The Blinding Light: The Uses of History in Constitutional Interpretation, 31 U. CHI. L. REV. 502 (1964).

142. Robert W. Bennett, Objectivity In Constitutional Law, 132 U. PA. L. REV. 445 (1984).

143. Richard A. Posner, Bork and Beethoven, 42 StAN. L. REV. 1365104 (1990).

144. James J. Brudney, Congressional Commentary on Judicial Interpretations of Statutes: Idle Chatter or Telling Response, 93 MiCH. L. REV. 1 (1994).

145. John F. Manning, The Absurdity Doctrine, 116 HARV. L. REV. 104 2387 (2005).

146. Abner J. Mikva, A Reply to Judge Starr's Observations, $1987 \quad 103$ DUKE L.J. 380 (1987).

147. Gary Lawson \& Christopher D. Moore, The Executive Power of 103 Constitutional Interpretation, 81 IowA L. REV. 1267 (1996).

148. Lawrence Lessig, Fidelity and Constraint, 65 FORDHAM L. REV. 103 1365 (1997).

149. Vesan Kesavan \& Michael Stokes Paulsen, The Interpretive Force of the Constitution's Secret Drafting History, 91 GEO. L.J. 1113 (2003).

150. Ronald M. Levin, The Anatomy of Chevron: Step Two Reconsidered, 72 CHI.-KENT L. REV. 1253 (1997).

151. * Adrian Vermeule, Legislative History and the Limits of Judicial Competence: The Untold Story of Holy Trinity Church, 50 STAN. L. REV. 1833 (1998).

152. William N. Eskridge, Jr. \& John Ferejohn, Super-Statutes, 50101 DUKE L.J. 1215 (2001).

153. McNollgast, Positive Canons: The Role of Legislative Bargains in Statutory Interpretation, 80 GEO. L.J. 705 (1992).

154. Peter C. Schanck, Understanding Postmodern Thought and Its Implications for Statutory Interpretation, 65 S. CAL. L. REV. 2505 (1992).

$\begin{array}{ll}\text { No. cites } & \begin{array}{l}\text { Weighted } \\ 105\end{array} \\ 105 & .194 \\ & .194 \\ 105 & .438 \\ 104 & .091\end{array}$

.139

.173

.217

.867

.153

.623

.264

.486

.259

.281

.374

.185

100 
APPENDIX B

GRAPH OF CITATION NETWORK

The draft graph below displays the citation connections among the articles in Appendix A. It was created using Gephi, an open-source graph visualization software package that allows the creation and analysis of directed social-network graphs. (Additional detail can be added to the graph to clarify the relations among subcategories of articles.)






\section{APPENDIX C \\ CitATION REFERENCE GRAPH}

This graph also shows the citation relations among the articles listed in Appendix A. Each row represents an article available for citation, ordered chronologically from top to bottom. Each column represents an article that could have made citations of another article in the appendix. An " $\mathrm{X}$ " marks the spot where each article listed in a column cites any prior articles listed in the rows. Thus, the patterns of citation over time may be read from left to right in the graph. 